$228+120+80$

ANL-7423

FHST REACTOR

$1 / 17169$

Argonne Mational Laboratoru

DESIGN AND ANALYSIS OF INSTRUMENTED

SUBASSEMBLY SYSTEM FOR EBR-II

by

A. Smaardyk, C. J. Divona,

R. H. Olp, and E. Hutter 
The facilities of Argonne National Laboratory are owned by the United States Government. Under the terms of a contract (W-31-109-Eng-38) between the U. S. Atomic Energy Commission, Argonne Universities Association and The University of Chicago, the University employs the staff and operates the Laboratory in accordance with policies and programs formulated, approved and reviewed by the Association.

\section{MEMBERS OF ARGONNE UNIVERSITIES ASSOCIATION}

The University of Arizona Carnegie-Mellon University Case Western Reserve University

The University of Chicago

University of Cincinnati

Illinois Institute of Technology

University of Illinois

Indiana University

Iowa State University

The University of Iowa
Kansas State University The University of Kansas Loyola University Marquette University Michigan State University The University of Michigan University of Minnesota University of Missouri Northwestern University University of Notre Dame
The Ohio State University Ohio University

The Pennsylvania State University

Purdue University

Saint Louis University

Southern Illinois University

University of Texas

Washington University

Wayne State University

The University of Wisconsin

\section{LEGAL NOTICE}

This report was prepared as an account of Government sponsored work. Neither the United States, nor the Commission, nor any person acting on behalf of the Commission:

A. Makes any warranty or representation, expressed or implied, with respect to the accuracy, completeness, or usefulness of the information contained in this report, or that the use of any information, apparatus, method, or process disclosed in this report may not infringe privately owned rights; or

B. Assumes any liabilities with respect to the use of, or for damages resulting from the use of any information, apparatus, method, or process disclosed in this report.

As used in the above, "person acting on behalf of the Commission" includes any employee or contractor of the Commission, or employee of such contractor, to the extent that such employee or contractor of the Commission, or employee of such contractor prepares, disseminates, or provides access to, any information pursuant to his employment or contract with the Commission, or his employment with such contractor.

Printed in the United States of America Available from

Clearinghouse for Federal Scientific and Technical Information

National Bureau of Standards, U. S. Department of Commerce

Springfield, Virginia 22151

Price: Printed Copy $\$ 3.00$; Microfiche $\$ 0.65$ 


\section{DISCLAIMER}

This report was prepared as an account of work sponsored by an agency of the United States Government. Neither the United States Government nor any agency Thereof, nor any of their employees, makes any warranty, express or implied, or assumes any legal liability or responsibility for the accuracy, completeness, or usefulness of any information, apparatus, product, or process disclosed, or represents that its use would not infringe privately owned rights. Reference herein to any specific commercial product, process, or service by trade name, trademark, manufacturer, or otherwise does not necessarily constitute or imply its endorsement, recommendation, or favoring by the United States Government or any agency thereof. The views and opinions of authors expressed herein do not necessarily state or reflect those of the United States Government or any agency thereof. 


\section{DISCLAIMER}

Portions of this document may be illegible in electronic image products. Images are produced from the best available original document. 


\author{
ARGONNE NATIONAL LABORATORY \\ 9700 South Cass Avenue \\ Argonne, Illinois 60439
}

\title{
DESIGN AND ANALYSIS OF INSTRUMENTED SUBASSEMBLY SYSTEM FOR EBR-II
}

\section{by}

\author{
A. Smaardyk, C. J. Divona, \\ R. H. Olp, and E. Hutter
}

\section{Major Contributors}
J.R. Folkrod
A. E. Knox
A. P. Grunwald
R.K. Lo
A. H. Heineman
G. F. Popper

W.M. Thompson

Reactor Engineering Division

\section{June 1968}

\section{LEGAL NOTICE}

This report was prepared as an account of Government sponsored work. Neither the United States, nor the Commission, nor any person acting on behalf of the Commission:

A. Makes any warranty or representation, expressed or implied, with respect to the accum racy, completeness, or usefulness of the information contained in this report, or that the use of any information, apparatus, method, or process disclosed in this report may not infringe privately owned rights; or

B. Assumes any liabilities with respect to the use of, or for damages resulting from the
B. use of any information, apparatus, method, or process disclosed in this report.

As used in the above, "person acting on behalf of the Commission" includes any employee or contractor of the commisston, or employee of such contractor, to the extent that such employee or contractor of the Commission, or employee of such contractor prepares, disseminates, or provides access to, any information pursuant to his employment or contract with the Commission, or his employment with such contractor. 
$\bullet$

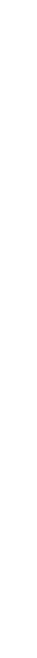

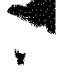

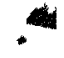

๑: 
TABLE OF CONTENTS

Page

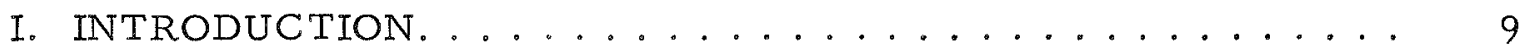

II. REFERENCE SYSTEM DESCRIPTION . . . . . . . . . 10

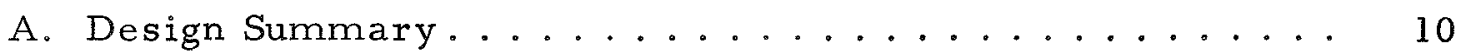

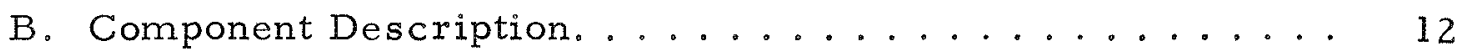

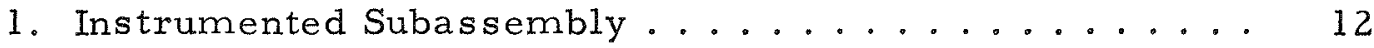

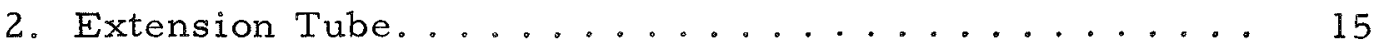

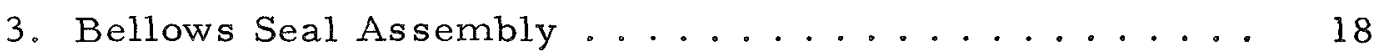

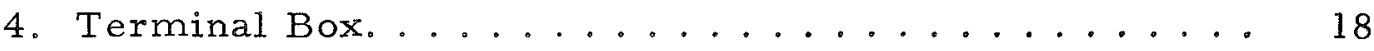

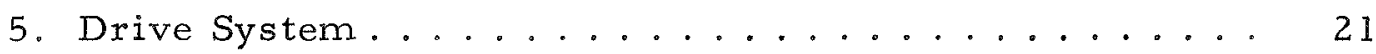

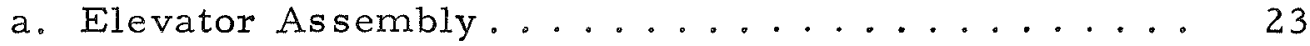

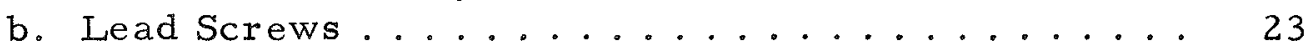

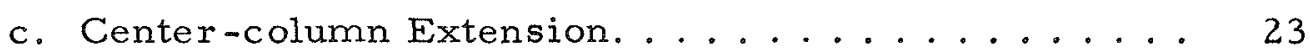

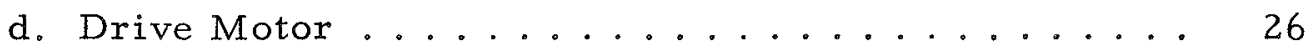

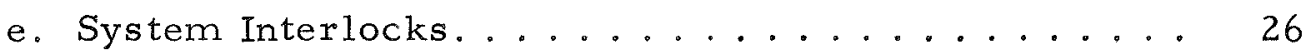

III. SUPPORTING RESEARCH AND DEVELOPMENT . . . . . . . 28

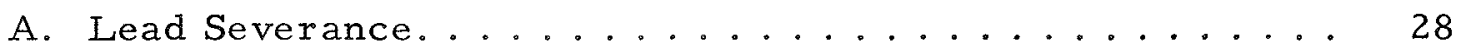

B. Assembly and Brazing of Instrument Leads ......... 29

C. Coupling of Subassembly and Extension Tube ....... 30

D. Full-scale Mockup Test Facility .............. 30

IV. PROTOTYPE INSTRUMENTED SUBASSEMBLY. . . . . . . . 32

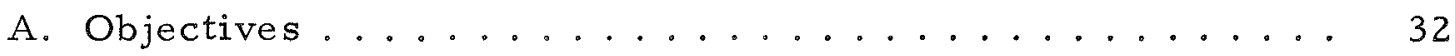

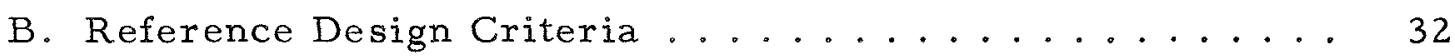

C. Nature of Instrumentation ................... 32

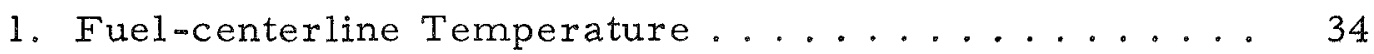

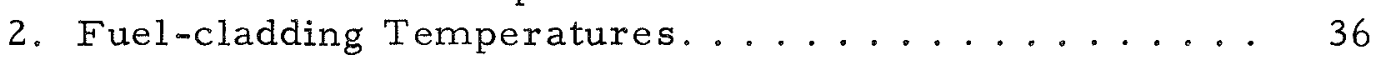

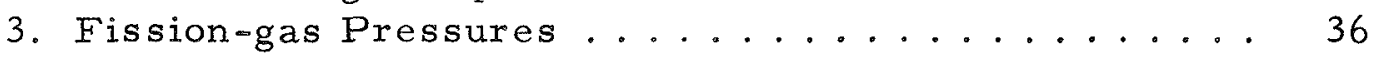

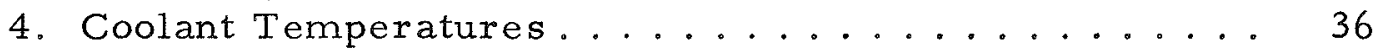

5. Coolant Flowrates..................... 37

D. Calculated Hydraulic Characteristics ........... 39

E. Shipment, Installation, and Removal ........... 41

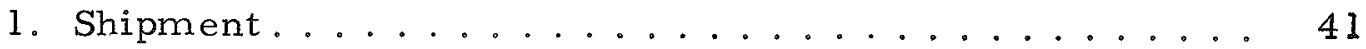

2. Installation ....................... 41 
TABLE OF CONTENTS

$\underline{\text { Page }}$

3. Removal ......................... 42

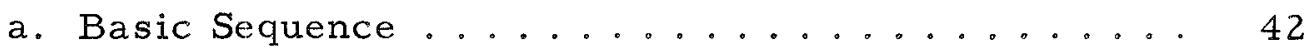

b. Separation of Extension Tube ............ 42

c. Dummy Assembly................... 43

d. Processing of Instrumented Subassembly ....... 46

F. Installation of Additional Instrumented Subassemblies . . . 46

ACKNOWLEDGMENTS ...................... 47

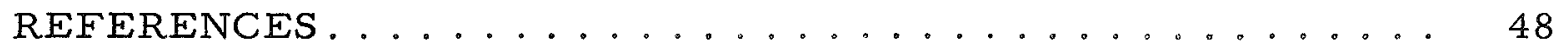




\section{LIST OF FIGURES}

No.

Title

Page

1. Proposed Instrumented Subas sembly System Installation in

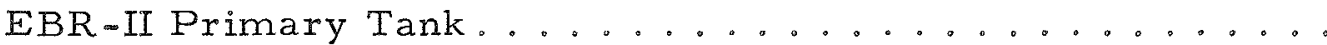

2. Sectional Views of Instrumented Subassembly and Testcapsule Arrangement ...................

3. Methods of Routing Lead Wires and Tubes from Subassembly

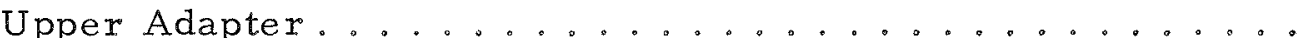

4. Test Mockup of Sheathed Lead Arrangement from Irradiation Test Capsule up through Drywell Bulkhead ...........

5. Instrument Lead Wire and Tube Connections above Drywell

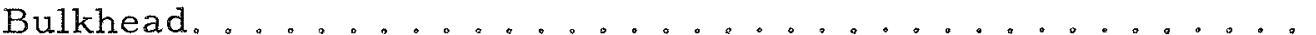

6. Components of Instrumented Subassembly System Installed atop Small Rotating Plug .................

7. Method of Connecting Bellows seal Assembly to Control rod

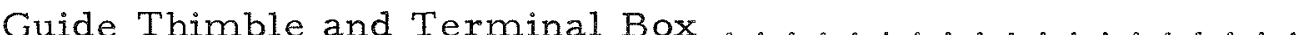

8. Terminal Box Showing Typical Connections of Subassembly Lead Wires and Tubes to Readout Instruments..........

9. Lead-screw-driven Elevator Assembly and Manner of Engagement to Guide Track on Central Support Column.....

10. Sectional Views of Aluminum Center-column Extension and Elevator assembly-guide Track ..............

11. Drive Motor-Gear Train-Lead Screw Assembly for Effecting Vertical Travel of Elevator Assembly.........

12. Microstructure of Braze between Type 304 Stainless Steel sheathed Thermocouple and Penetration in Type 304 Drywell

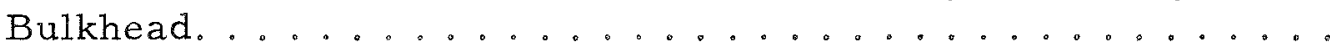

13. Full-scale Mockup Test Facility for Evaluating Performance of Independent and Integrated Components of Instrumented

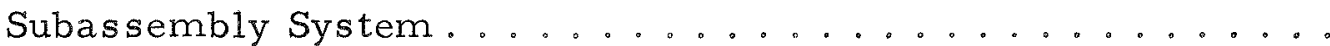

14. Installation of Fuel and Cladding Thermocouples and Fissiongas Pressure Transducer in Irradiation Test Capsule......

15. Permanent-magnet Flowmeter Installation in Bottom Adapter

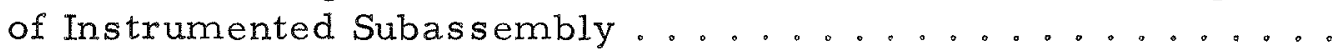

16. Calculated Total Pressure Drop in Prototype Instrumented Subassembly with and without Flowmeter...........

17. Mathematical Models and Calculated Velocity and Flow Distribution in Instrumented Subassembly. 


\section{LIST OF FIGURES}

No.

Title

Page

18. Linear Dimensions of Integrated Prototype Unit To Be Shipped

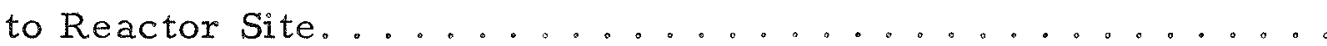

19. Cutting Tool Assembly for Severing Leads from Prototype Instrumented Subassembly . . . . . . . . . . . . 44

20. Dummy Extension Tube-Shield Plug Assembly Used to Temporarily Seal Opening in Rotating Plug and Reactor

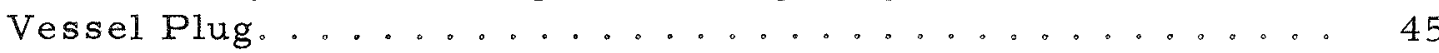

21. Preferred Multiple Instrumented Subassembly Installation in $\mathrm{EBR}-\mathrm{II} \ldots \ldots \ldots \ldots \ldots \ldots$ 


\section{LIST OF TABLES}

No。

I. Reference and Alternative Design Criteria for Instrumented Subas sembly Installations in EBR-II ............ 33

II. Design Characteristics of Instrument-lead Assemblies for

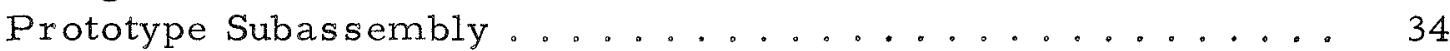

III. Criteria Used in Hydraulic Analysis of Prototype

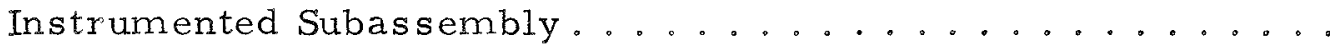




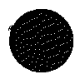

- 


\title{
DESIGN AND ANALYSIS OF INSTRUMENTED SUBASSEMBLY SYSTEM FOR EBR-II
}

by

\author{
A. Smaardyk, C.J. Divona, \\ R. H. Olp, and E. Hutter
}

\section{INT RODUCTION}

Originally designed and operated to demonstrate the feasibility of liquid-metal-cooled fast-breeder-reactor central-station power plants, EBR-II has since become the primary fast flux irradiation facility for evaluating advanced fuels of interest to the AEC Liquid Metal Fast Breeder Reactor (LMFBR) Program. Consistent with this new role, Argonne Reactor Engineering Division staff members have collaborated with AECsponsored experimenters in the design of in-core subassemblies to enhance the irradiation test capability of the reactor.

Of the seven models evolved thus far, two types (Mark A and MarkB) have been used by various experimenters since May 1965 and have yielded postirradiation data; the others are in various stages of prototype develop ment and testing. Starting with Mark A, each model represents an improvement in capacity of fuel specimens, nature of exposure (capsulated or uncapsulated), or internal structure to accentuate environmental conditions within the subassembly (e.g., modification of flow scheme to permit higher fuel temperatures in the specimen). However, none of the models is designed to provide continuous behavioral data on the specimens which can be correlated to the overall environment prevailing throughout the test.

Accordingly, early in 1966 a study was made to determine the feasibility of installing an instrumented subassembly system capable of measuring pertinent operating parameters of specimen fuels and related components while under irradiation in the EBR-II core. Emphasis was placed on:

(1) maximum experimental flexibility, particularly with respect to the type and disposition of the instrument sensors within the subassembly: (2) compatibility of the system with existing reactor equipment and normal fuelhandling procedures; and (3) minimum reactor shutdown time for installation and removal of the system components.

This report describes the research, design, and development work performed after the feasibility study. ${ }^{1}$ The immediate objective is construc tion of a prototype system for installation and performance evaluation in the EBR-II during the first quarter of calendar year 1969. Subject to this eval uation and successful development of higher-worth control subassemblies, which would permit reactor operation with eight instead of the current twelve units, the ultimate objective is to install up to four instrumented subassembly systems. 


\section{REFERENCE SYSTEM DESCRIPTION}

A. Design Summary

Figure 1 is an artist's concept of the proposed instrumented subassembly system installation in the EBR-II primary tank. The system consists of: (1) the instrumented subassembly, which is installed in a vacated control subassembly position in the core; (2) an extension tube with an internal coupling, which engages the end fitting of the subassembly; this tube is also used to route lead wires and tubes from within the subassembly: (3) a bellows seal assembly, which seals the control-rod opening in the rotating plug through which the extension tube operates; (4) a terminal box, where lead wire and tube connections are made with external readout instruments; (5) an elevator assembly for raising or lowering the terminal box-extension tube-subassembly complex; and (6) a drive motor and gear train for imparting rotational movement to two lead screws, which effect vertical travel of the elevator assembly.

The terminal box, extension tube, and subassembly are installed completely preassembled and checked out. Unlike the standard control subassemblies, the instrumented subassembly is engaged and supported by the extension tube throughout the irradiation test, including normal fuelhandling operations. Preparatory to these operations, the extension tube and subassembly are raised $8 \mathrm{ft}$ to clear the tops of adjacent subassemblies in the reactor vessel, whereas the standard control subassemblies are disconnected to permit indexing of fuel-transfer mechanisms and drives mounted on the small and large rotating plugs.

After the irradiation experiment, the subassembly is lowered 1 in. to rest on the core support grid, the elevator assembly is disconnected from the terminal box, and the box is removed. At this point, the coupling assembly is disengaged from the end fitting and withdrawn, while the extension tube restrains the subassembly from upward movement.

Next, a special cutting - tool assembly is lowered through the extension tube. This tool is rotated to sever the instrument leads and tubes that protrude from the subassembly upper adapter. After the severance operations, the extension tube and the cutting tool are withdrawn into a pulling tube and transferred to a storage location. Finally, the instrumented subassembly is removed from the reactor vessel to the primary-tank storage basket.

If available, a fresh terminal box-extension tube-instrumented subassembly unit is lowered into position and attached to the elevator assembly. If the unit is not available, a dummy subassembly is temporarily loaded into the reactor vessel via the storage rack. In addition, a dummy extension tube (actually a shield-plug assembly) is lowered into the tank to seal the 


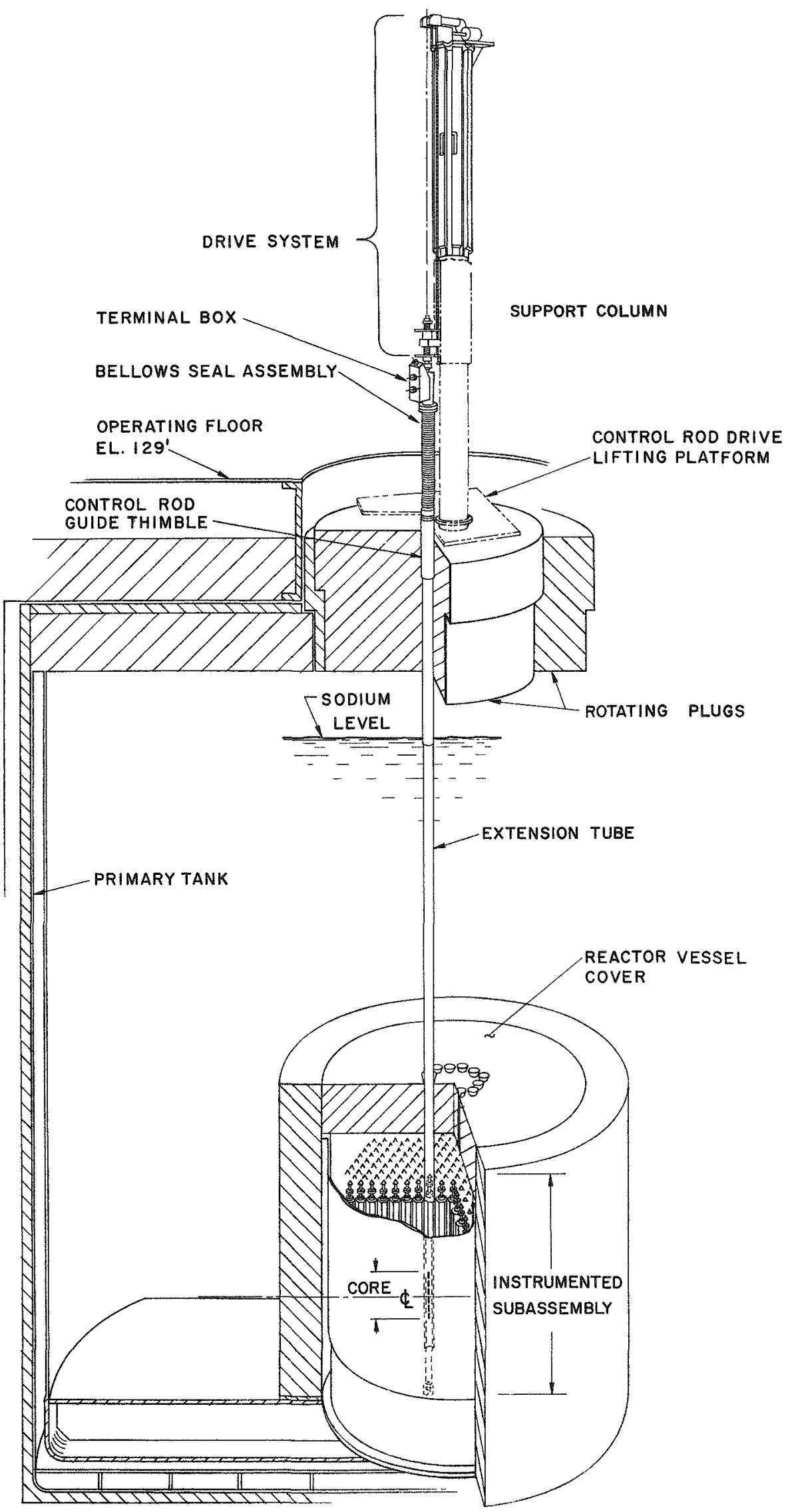

Fig. 1. Proposed Instrumented Subassembly System Installation in EBR-II Primary Tank 
opening in the small rotating plug and the control-rod-guide sleeve in the reactor-vessel cover. This dummy tube is suspended by the elevator assembly to within $1 / 4$ in. of the dummy-subassembly end fitting.

After a prescribed decay period, the irradiated instrumented subassembly is removed from the storage basket into the interbuilding transfer coffin for transport to the air cell in the Fuel Cycle Facility. Here, the unit is disassembled and the irradiation test capsules or elements are prepared for off-site shipment.

\section{B. Component Description}

The following component descriptions are made with reference to Fig. 1, starting with the instrumented subassembly shown installed in the reactor vessel.

\section{Instrumented Subas sembly}

Outwardly, the configuration of the instrumented subassembly is identical to that of a standard control-rod subassembly ${ }^{2}$ it replaces. It consists of a lower adapter and an upper adapter, which are welded to a hexagonal tube that forms the body of the subassembly. As shown in Fig. 2, the subassembly fits within the standard guide thimble employed for all control-rod positions and is compatible, in every respect, with existing fuel-handling equipment, procedures, and storage facilities.

The subassembly body can accommodate a maximum of nineteen 0.357 -in.-OD, 0.317 -in.-ID capsules or thirty-seven 0.250-in.-OD, 0.220-in, -ID capsules of specimen fuel or structural materials, along with instrumentation for monitoring their behavior and the corresponding test environment. All capsules have an irradiation length of $40 \mathrm{in}$, and, depending upon the loading, each is spaced laterally with attached spiral wires of 0.041- or 0.040-in. diameter. Where coolant thermocouples are attached to the outside of the capsules, their leads are wound around the capsule in place of the spacer wires. Each capsule is supported vertically on a grid that permits upward flow of sodium coolant through the capsule array.

Tentatively, the instrumentation includes thermocouples, pressure transducers, and a flowmeter for measuring fuel centerline-cladding temperatures, fission-gas pressures, and coolant temperatures and flowrates. One or more of the support-grid positions may be occupied by a conduit for routing leads from an inlet coolant thermocouple and flowmeter installed within the lower adapter. The conduit is used to install a closedend tube for a miniature flux monitor.

To accommodate installation of a flowmeter, the lower shield section common to standard control-rod subassemblies has been modified 


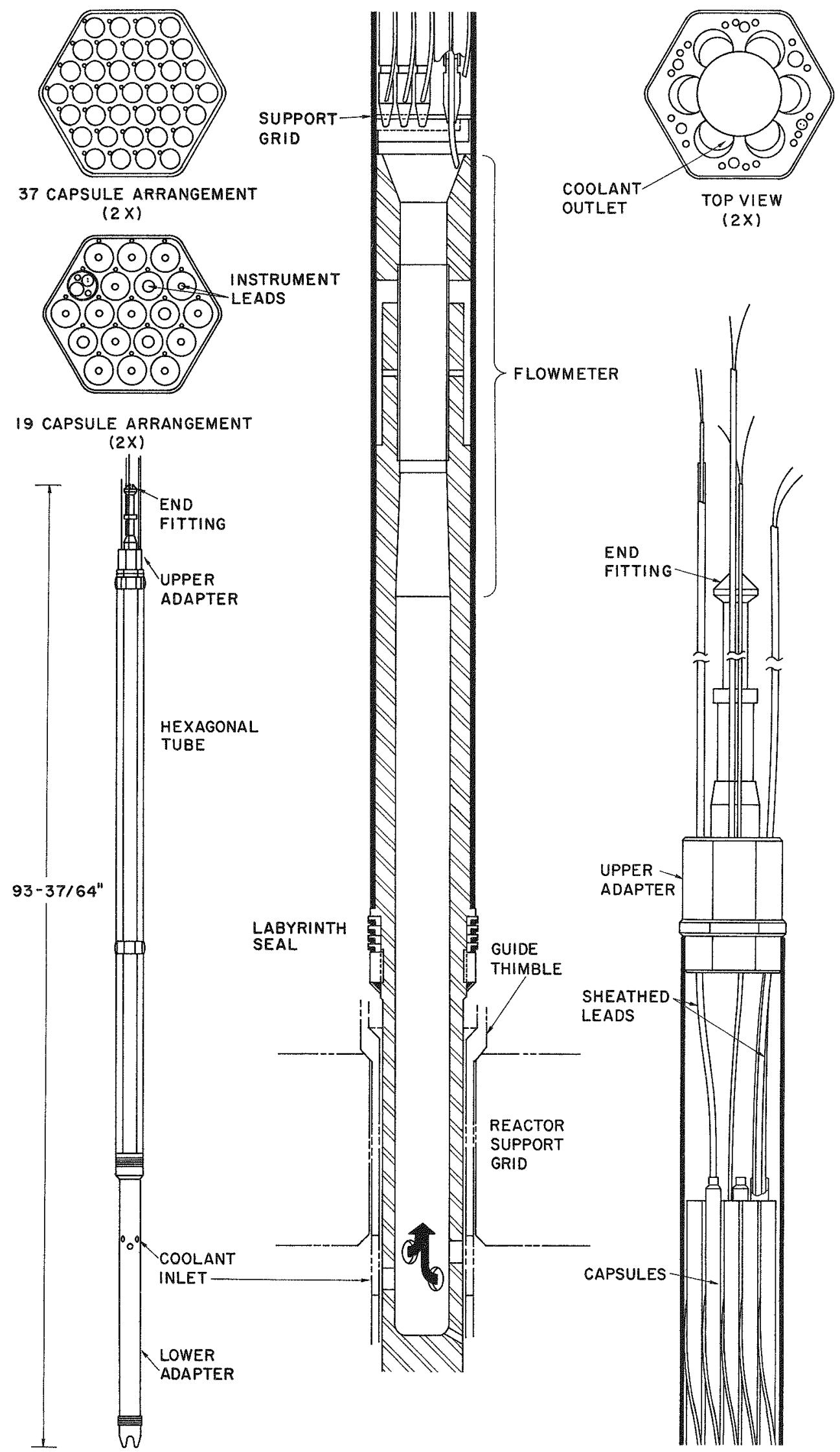

Fig. 2. Sectional Views of Instrumented Subassembly and Test-capsule Arrangement 
to form a 12-in.-long flow-straightening duct, which leads to the flowmeter conduit. To compensate for the loss of shielding in this region, the balance of the lower adapter below the inlet coolant orifices ( 12 in.) is fabricated of solid stainless steel.

The standard upper adapter-end fitting is pierced with six 29/64-in.-diam coolant outlets and a number of smaller holes for passage and support of the instrument leads. These leads extend into the extension tube to which the subassembly is coupled. As shown in Fig. 3, the lower end of the tube is also pierced with 3/4-in.-diam holes through which the sodium coolant discharges.

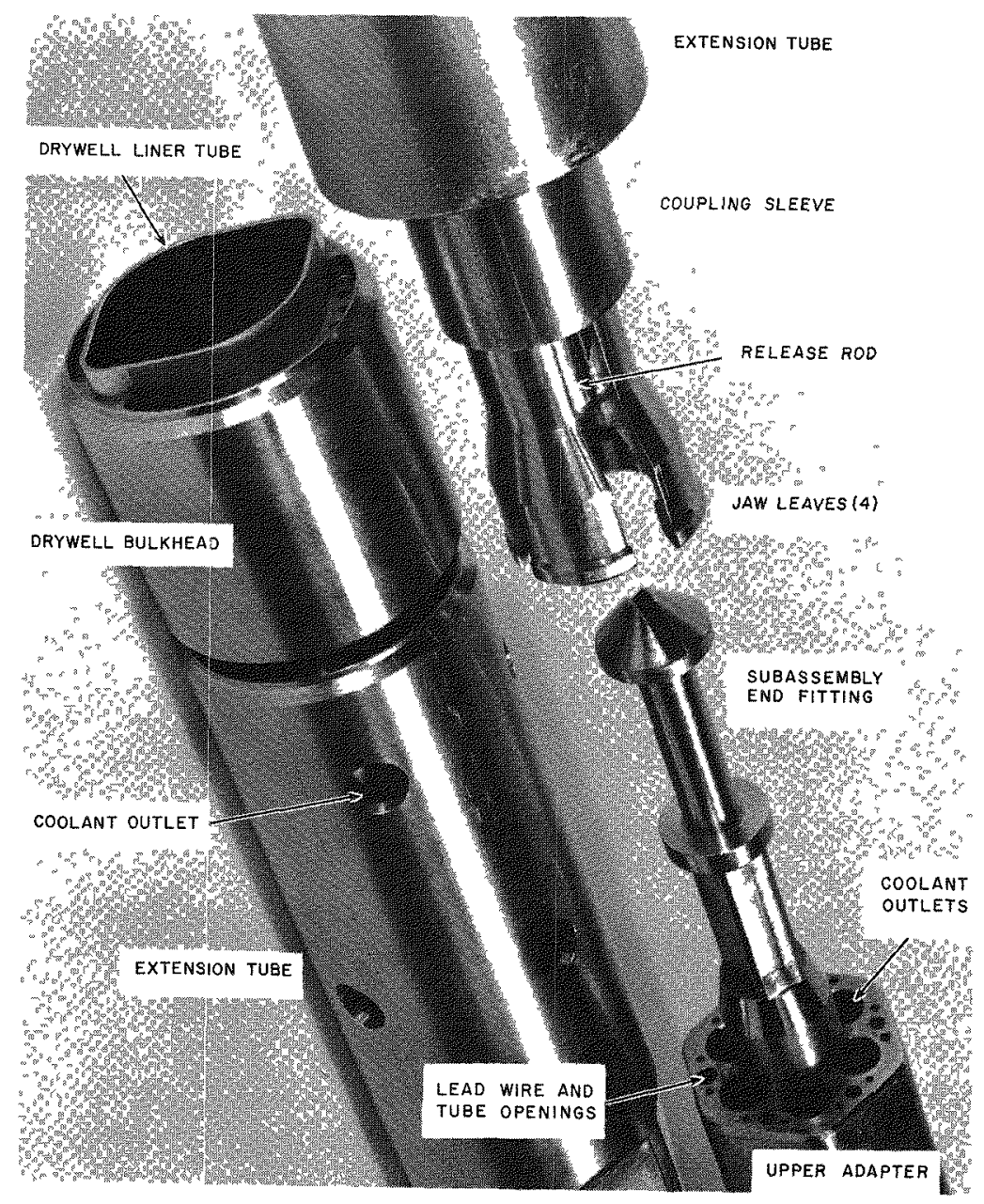

$112-9878-\mathrm{A}$

Fig. 3. Methods of Routing Lead Wires and Tubes from Subassembly Upper Adapter. Lead wires and tubes from subassembly upper adapter are routed through lower section of extension tube, drywell bulkhead, up through dry well, into terminal box. Drywell liner tube is welded to tube stub in bulkhead. Upper section of extension tube, drywell bulkhead, and lower section of extension tube are welded closed and clipped over subassembly upper adapter. Jaw leaves are lowered over end fitting, release rod is lifted, and coupling sleeve is lowered around leaves to effect eng agement. 


\section{Extension Tube}

The extension tube serves as a rigid connecting link between the instrumented subassembly and the drive system, and for routing of instrument leads to the terminal box above the rotating plugs (as shown in Fig. 1). The lower end of the extension tube slips over the hexagonal subassembly upper adapter, and the end fitting is engaged by a coupling assembly inside the tube.

As shown in Fig. 3, the coupling assembly consists of (1) a central rod, which may be used to release four tapered jaws, which engage the end fitting; these jaws are part of four 18-in.-long leaves attached to a tubular sleeve, which, along with the release rod, is threaded into a spring-supported flange in the terminal box; and (2) a coupling sleeve, which retains the jaws in the engaged position. This mode of coupling was selected to ensure fixed orientation of the subassembly throughout ir radiation testing (including normal reactor-fueling operations), and absorption of torsional reactions by the extension tube during severance of leads within the subassembly.

In operation, the coupling sleeve restricts outward deflection of the jaws, and the segmented leaves are in tension. As evidenced by laboratory tests, the tensile strength of the four leaves is sufficient to support the subassembly, with a considerable margin for unexpected loads. During actual irradiation testing, the subassembly is suspended with the upper adapter 1 in. higher than those of adjacent subassemblies. Some differential expansion between the coupling and extension tubes may occur; therefore, the springs at the top of the extension tube are designed to compensate for an expansion of $11 / 32 \mathrm{in}$. between the total submerged lengths of these components.

After testing, and preparatory to lead severance, the extension tube is lowered to place the adapter at the proper elevation. At this point, the coupling sleeve is subjected to a vertical upward force, and the taper in each jaw produces a force component in the radial outward direction. As the sleeve rises above the conical end fitting, the force component spreads the confining jaws to effect uncoupling.

Sheathed leads as well as tubes from various sensors in the subassembly are routed through penetrations in the bulkhead of a dry well formed by an inner oval tube and the outer extension tube. These penetrations are then sealed with a brazing compound. Two feet above the bulkhead, the sheathed leads are attached to conventional, flexible lead wires, and in the case of tubes, appropriate connections are made. Figure 4 shows a test mockup of the proposed lead arrangement. Figure 5 illustrates the manner in which lead wire and tube connections are made above the drywell bulkhead. 


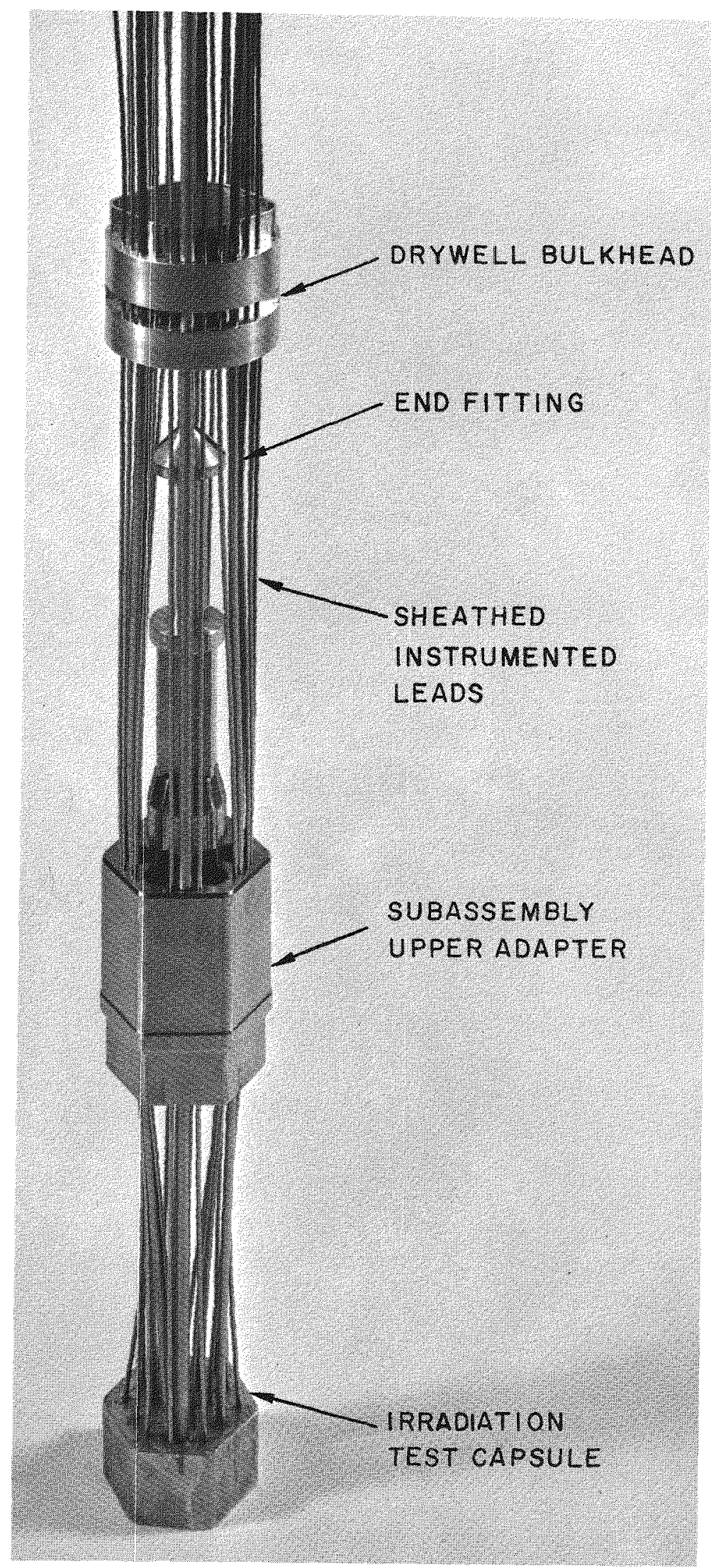

$112-9353-A$

Fig. 4. Test Mockup of Sheathed Lead Arrangement from Irradiation Test Capsule up through Drywell Bulkhead 


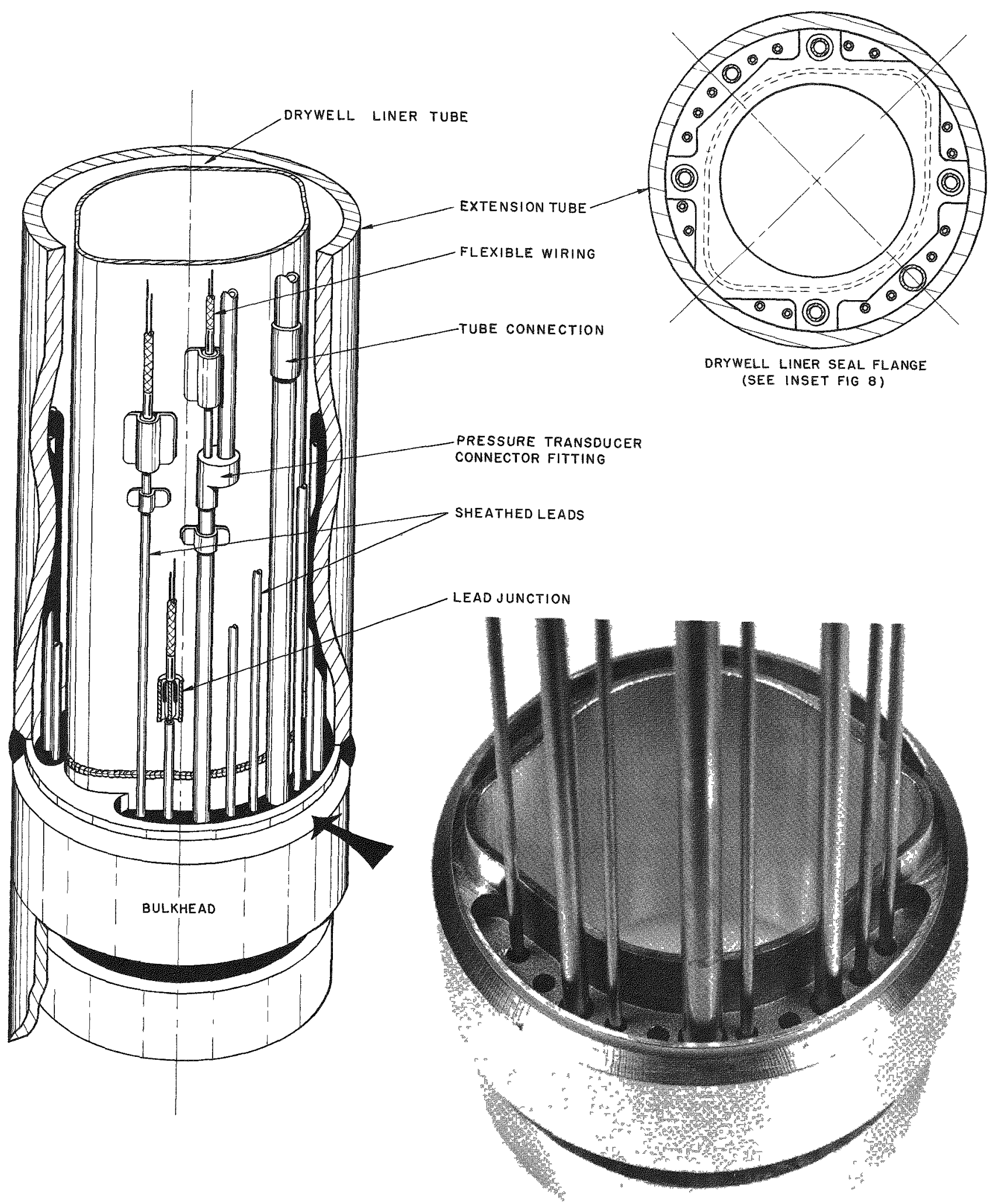

Fig. 5. Instrument Lead Wire and Tube Connections above Drywell Bulkhead. Wires and tubes are brazed in bulkhead penetrations. 
Use of the terminal box for making lead-wire and tube connections was deferred in favor of the drywell concept for several reasons:

(1) Possible differential expansion and support problems associated with long sheathed leads are avoided.

(2) A relatively large number of short sheathed leads in the drywell bulkhead may be readily sealed.

(3) Tube connections and attachment of flexible wires to sheathed leads are more easily effected in the uncovered bulkhead region than in the confined area of the terminal box.

The following design descriptions pertain to components installed above the small rotating plug. With reference to Fig.6, these include the bellows seal assembly, the terminal box, the drive system, and system interlocks.

\section{Bellows Seal Assembly}

The functions of the bellows seal assembly are to prevent outleakage of blanket gas from the primary tank and to accommodate $8 \mathrm{ft}$ of extension-tube travel through the control-rod guide thimble in the small rotating plug. Figure 7 shows the manner in which both functions are accomplished.

The bellows seal assembly is fabricated of Type 347 stainless steel and consists of an upper flange, which is $\mathrm{O}-\mathrm{ring}-\mathrm{sealed}$ to the top flange of the extension tube; 900 nesting convolutions (3.7-in. OD, 2.59-in. ID), which are welded by a tungsten-inert gas technique; and a lower end fitting, which threads onto and depresses an O-ring seal in the control-rod guide thimble.

The convolutions vary in thickness from 0.010 in. in the upper section to $0.006 \mathrm{in}$. in the central and lower sections. This variation results in a reasonably uniform mechanical-stress distribution during extension and compression of the bellows, and eliminates the need for external strap hangers to limit excessive stresses in the upper convolutions. When compressed, the bellows seal assembly is $34 \mathrm{in.}$ long; it may be extended $104 \mathrm{in.}$ The unit has been designed for a minimum operating lifetime of 10,000 cycles and a maximum internal gas pressure of 10 psi.

\section{Terminal Box}

All connections between internal and external instrument leads and tubes are made through hermetically sealed multipin connectors and tube fittings installed in the terminal box. Fabricated of Type 304 stainless steel, this box has an integral semicylindrical adapter, which is flanged at 


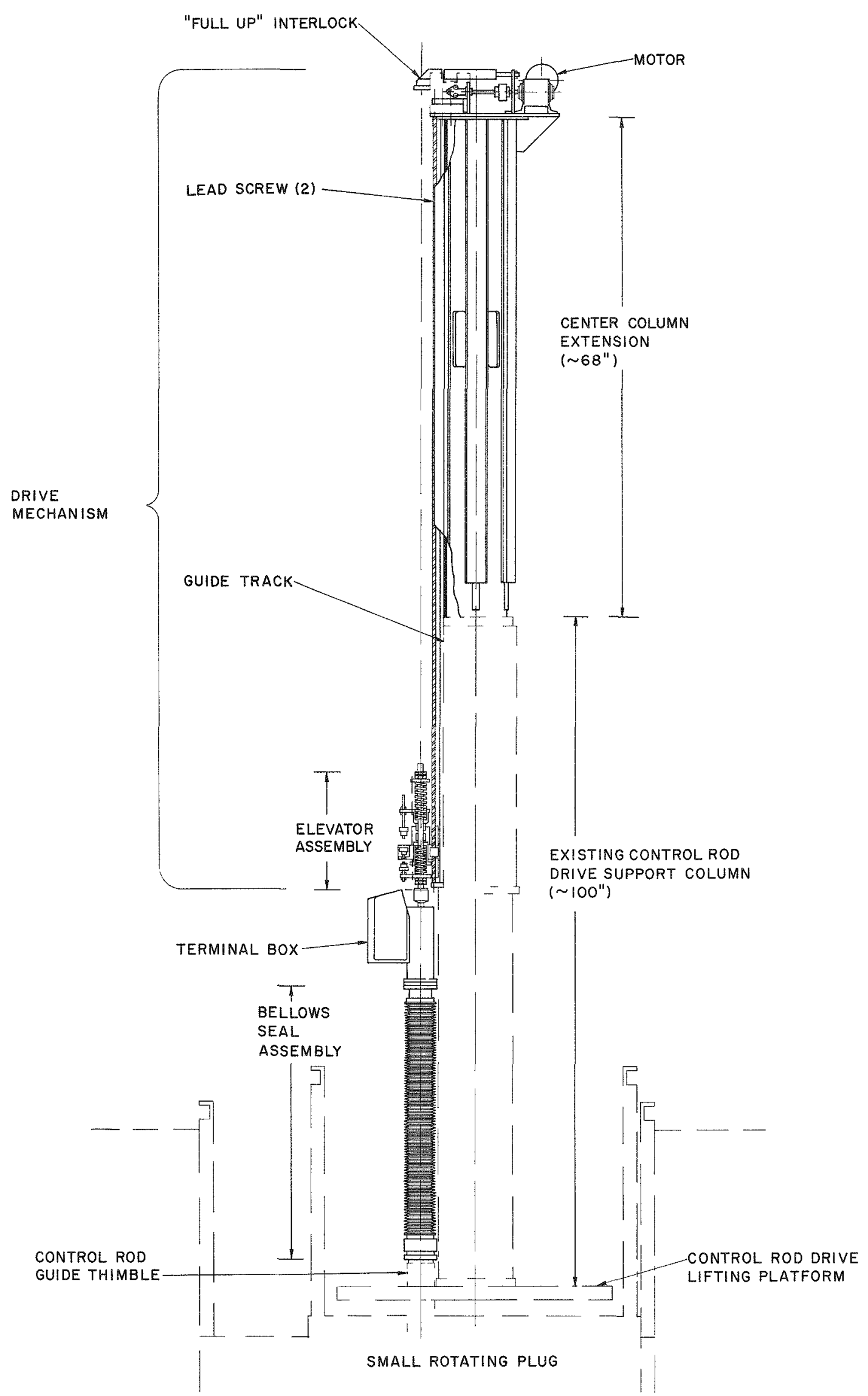

Fig. 6. Components of Instrumented Subassembly System Installed atop Small Rotating Plug 


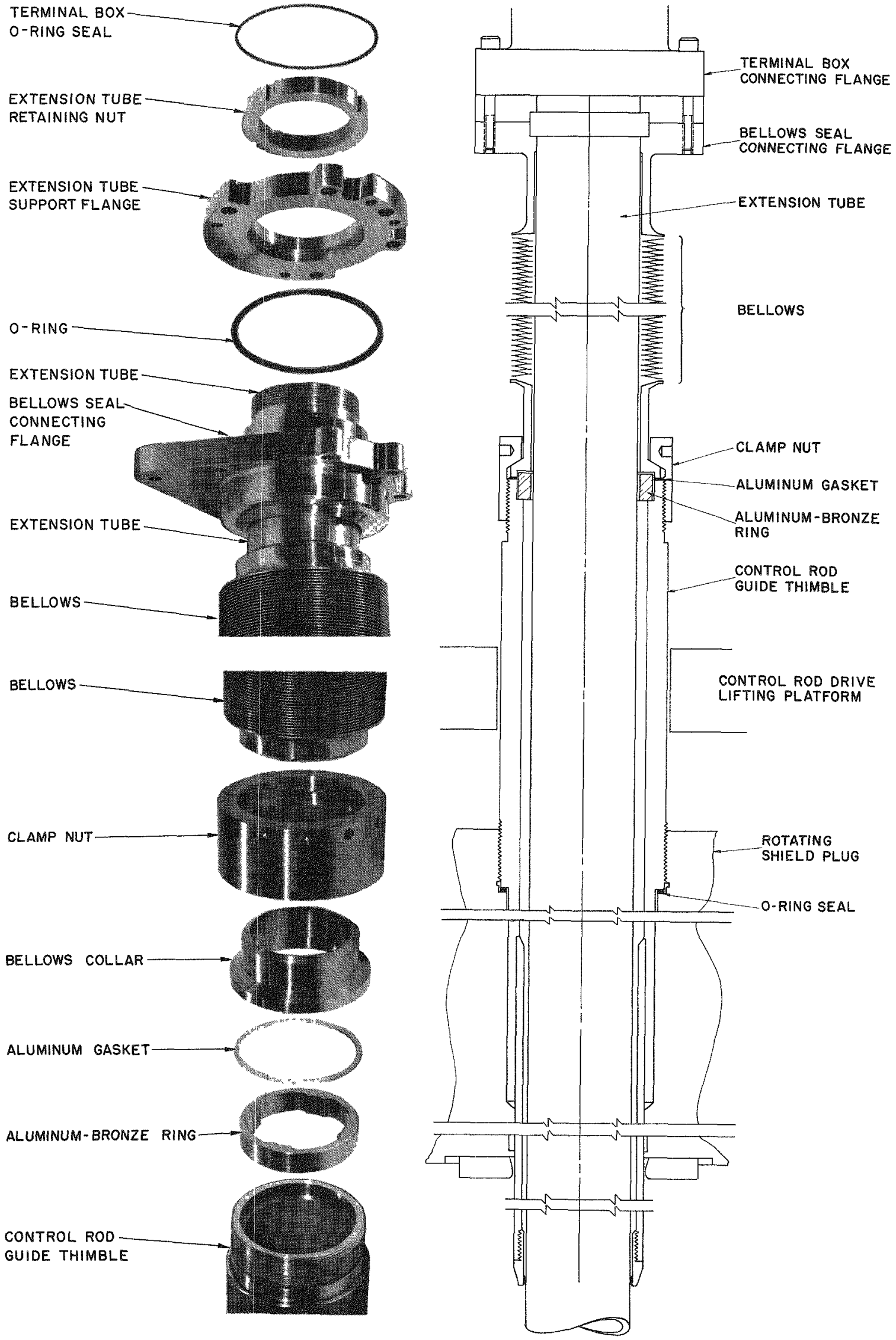

Fig. 7. Method of Connecting Bellows Seal Assembly to Control-rod Guide Thimble and Terminal Box 
the bottom. This flange is sealed to the mating flange on the extension tube. An argon pressure of 14 psig is maintained in the terminal box. This pressure is higher than the gas pressure in the extension tube; hence any seal leakage would be from the terminal box into the extension tube. Apressuresensing switch is installed to detect a pressure drop in the terminal box.

As shown in Fig. 8, instrument lead wires and tubes from the extension tube pass up through the flange and the adapter and into the terminal box. Connections within the box are made by removing access covers in the front and side walls.

The top of the terminal box is bolted to the flange of the elevator assembly.

\section{Drive System}

The drive system supports the extension tube and instrumented subassembly in the vacated control-rod position during irradiation test, and raises the subassembly $8 \mathrm{ft}$ to clear the reactor vessel preparatory to normal fuel-handling operations. Moreover, the system components form a compact assembly that can be mounted to service an instrumented subassembly installed in any of the 12 control-rod positions in the reactor.

Starting at the top of Fig. 6, these components include:

(1) A drive motor with a torque-limiting clutch and gear train for rotating two lead screws to raise or lower the elevator assembly. This drive unit is mounted on top of a lightweight extension of the existing central column, which supports the 12 control-rod drives. Both columns are supported by the control-rod lifting platform, which, in turn, is mounted on the small rotating shield plug. Also attached atop the column extension is an interlock, which ensures locking of the elevator assembly (and instrumented subassembly) in the "full-up" position before the plug can be rotated.

(2) A V-shaped, 100-in.-long guide track for aligning the elevator assembly throughout its vertical travel. This track is bolted to the column extension and between the bosses of the support column to which the control-rod drives are attached. Initially, one track will be installed for the prototype; additional tracks will be installed as required.

(3) An elevator assembly equipped with an elevator arm (which engages the guide track), limit switches, a load-sensing device, and a flange (which attaches to a mating flange atop the terminal box).

The drive mechanism has a normal vertical stroke of 96 in. Some overtravel ( 3 in.) is available for additional adjustments of the elevator assembly. 


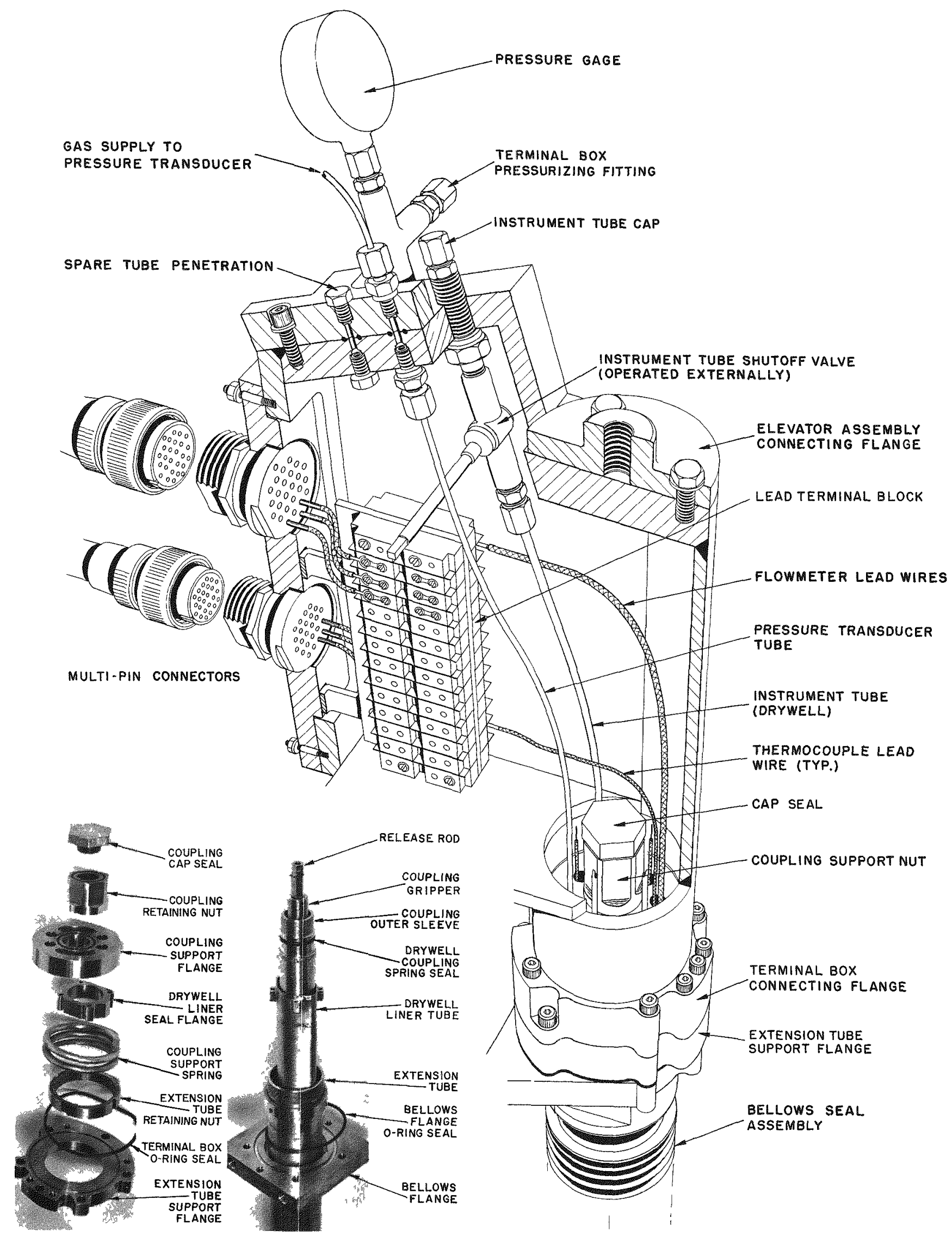

Fig. 8. Terminal Box Showing Typical Connections of Subassembly Lead Wires and Tubes to Readout Instruments. Inset shows exploded view of extension tube-coupling support and sealing arrangement. 
a. Elevator Assembly. During irradiation test and subsequent withdrawal for fuel-handling operations, the terminal box, extension tube, and subassembly are suspended from the elevator assembly. This assembly consists of an elevator arm and a connecting link through which the arm is engaged to the terminal box.

With reference to Fig. 9, the elevator arm is the main supporting member; it engages a V-shaped guide track on the central support column. The arm houses the ball-bearing nuts through which the two lead screws rotate to effect vertical travel of the elevator assembly. The arm also houses a central spherical bearing and supports upper and lower limit switches, which interrupt vertical travel of the elevator assembly if preselected load limits are exceeded.

The connecting link consists of a 0.875 -in.-OD, 19-in.-long spring-supported rod fabricated of Type 304 stainless steel, an end yoke, a force transducer, and two support springs. The rod is bolted at the top to a support block, which also supports an upper-limit-switch contact. The rod extends down through the spherical bearing and threads into the yoke. The yoke is pin-connected to the force transducer, which, in turn, is flanged to the top of the terminal box.

Both connecting-rod springs are preadjusted for support of the extension tube and subassembly. The limit switches on the elevator arm are connected in series with the drive-motor control circuitry; they are actuated by relative movement between the connecting rod and elevator arm in the event of excessive spring deflection. The transducer monitors the lifting forces during vertical movement of the subassembly.

b. Lead Screws. Both lead screws and ball-bearing nuts are standard manufactured items. Each has a static load capacity of 3,150 1b and a dynamic load capacity of $600 \mathrm{lb}$. Since the total load (extension tubesubassembly) is estimated at $300 \mathrm{lb}$, there is an adequate margin for unexpected loads.

As shown in Fig. 9, both lead screws are located close to the central support column (inside, rather than outside, the subassembly centerline). This eliminates the need for an outside frame support for the screws. Also, with the screws in this location, only the elevator arm need be detached to facilitate removal of the extension tube and "fuel handling" of the subassembly.

c. Center-column Extension. The center-column extension (shown in Fig. 10) rises 68 in. above the top of the existing central-support column to which it is bolted. The extra height is required to accommodate the 8-ft vertical travel of the subassembly. (Note: The control-rod drives have a 14-in. stroke.) 


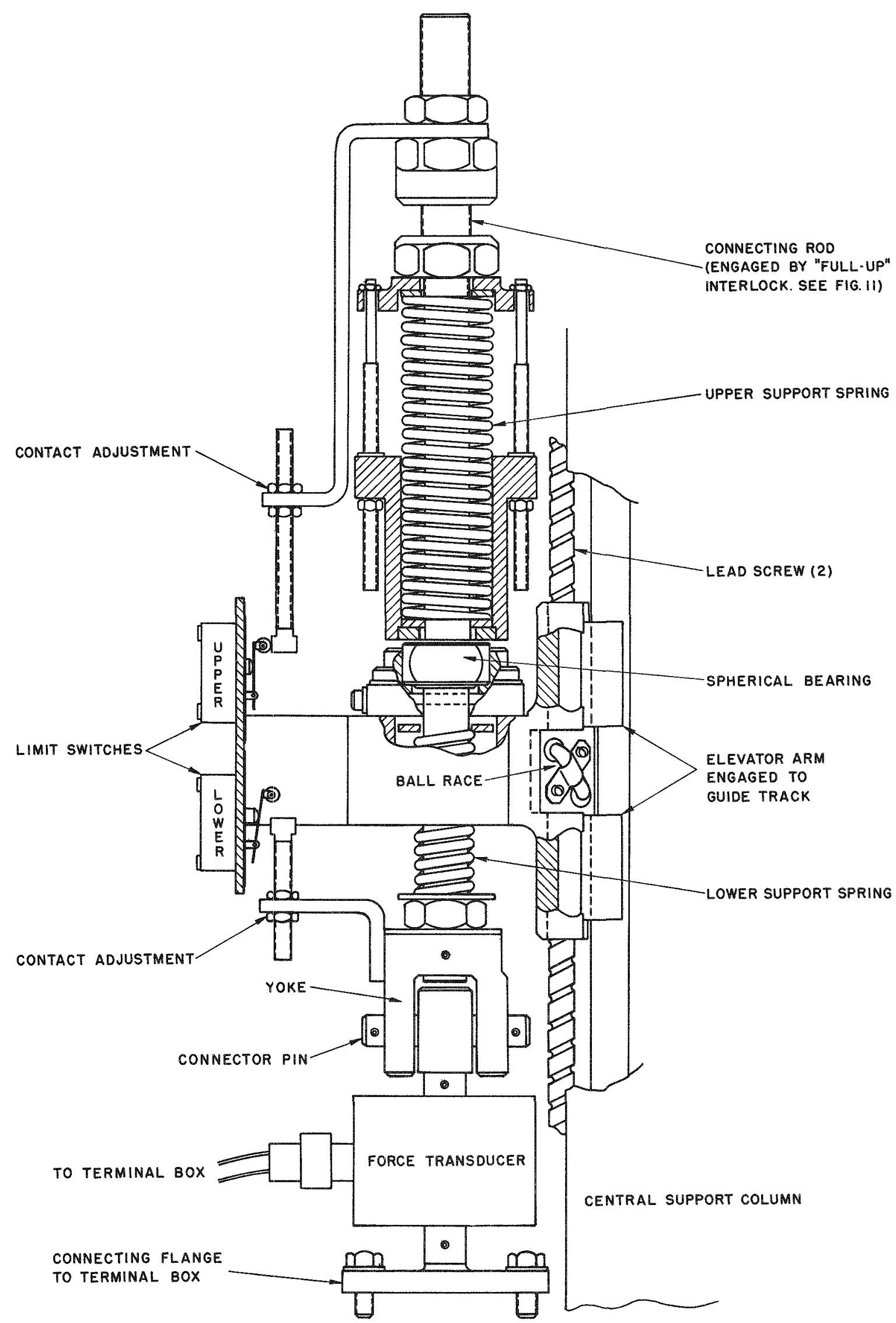

Fig. 9. Lead-screw-driven Elevator Assembly and Manner of Engagement to Guide Track on Central Support Column. Limit switches have been rotated $90^{\circ}$ for clarity. 


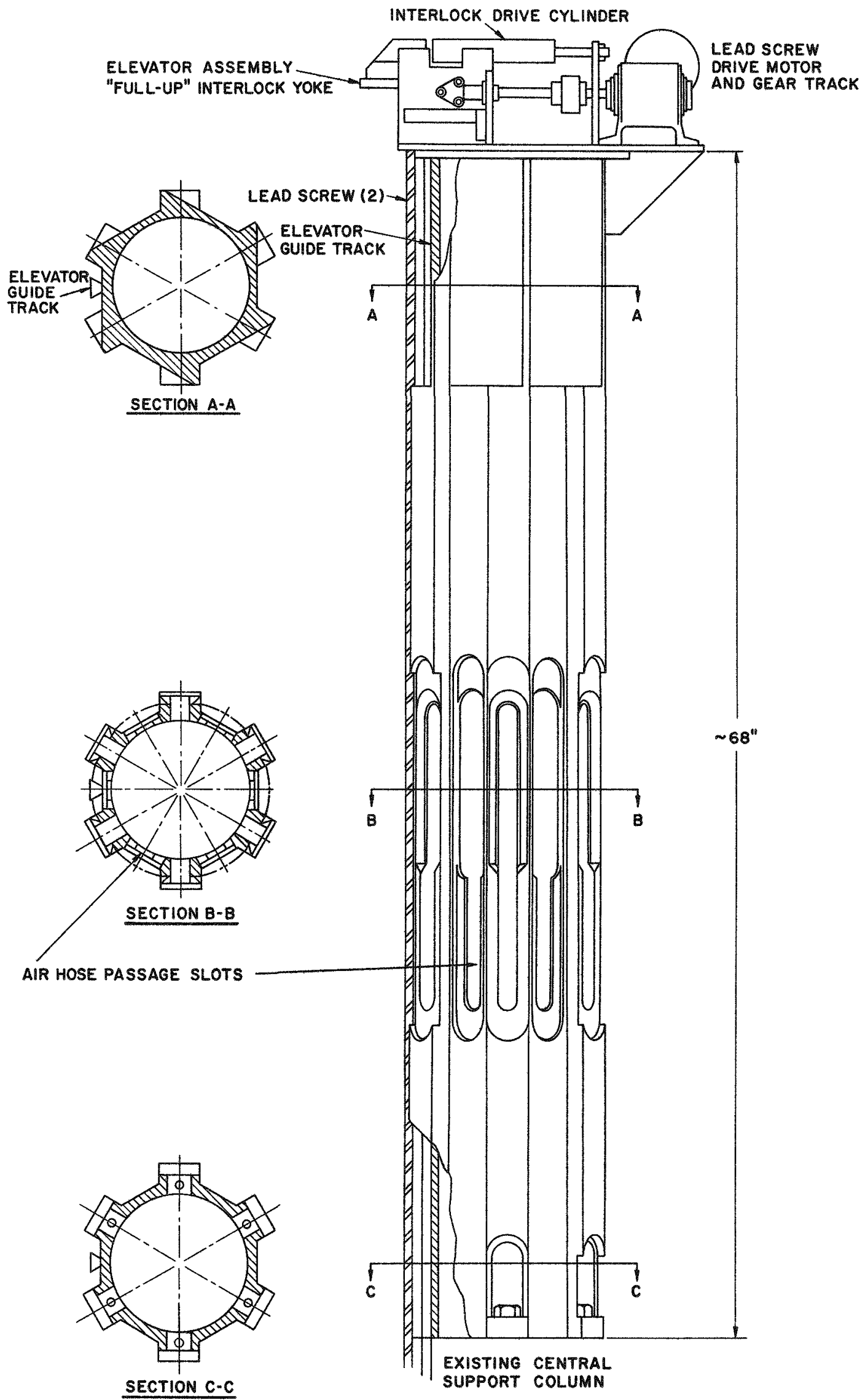

Fig. 10. Sectional Views of Aluminum Center-column Extension and Elevator-assembly-guide Track 
With reference to Fig. 10, the configuration of the column extension is similar to that of the main-support column. Twelve vertical channels are equally spaced in the outer surface; they are aligned with similar channels in the main support column and accommodate the elevatorassembly-guide track. In addition, 12 slots axe machined midway around the column extension. These slots permit passage of hoses which interconnect the internal air tank and control-rod-drive air cylinders. To minimize the additional weight to be supported by the main column, the extension is fabricated of 10.5-in.-OD, 1.25-in.-wall Type 7075 seamless aluminum pipe.

d. Drive Motor. The system is operated by a three-phase, ac, reversing gear motor having the following operating characteristics: motor speed, $1725 \mathrm{rpm}$; geared shaft speed, $12 \mathrm{rpm}$; torque output, $140 \mathrm{in.-1b}$. The torque required for lifting the extension tube-subassembly unit is estimated at 65 in. $-1 b$.

With reference to Fig. 11, the motor output shaft drives a mechanical torque limiter and a backstopping clutch. (This clutch automatically locks the drive train when the motor is stopped.) The output shaft of the clutch drives a 1:1 right-angle gear, whose output shaft, in turn, drives a gear train. The latter drives the two lead screws at $30 \mathrm{rpm}$, to result in vertical travel of the elevator assembly at $15 \mathrm{in.} / \mathrm{min}$.

e. System Interlocks. The following interlocks are to be incorporated into the existing circuitry of the fuel-handling console:

(1) The drive mechanism cannot be operated unless the rotating shield plugs are in their "operating" position.

(2) Rotation of the plugs for normal fuel handling cannot begin unless the elevator assembly is in the "full-up and locked" position. As shown in Fig. 11, this position is effected by a sliding yoke and attached limit switch, which is moved under the elevator assembly. The switch is installed so that it can be depressed only when the elevator is in the "full-up" position and the yoke is actuated. The yoke is extended and retracted pneumatically. Air is supplied from a cylinder through four-way, four-port solenoid valve. This valve is energized upon contact between the elevator assembly and a microswitch installed on top of the extension column.

(3) Whenever excessive forces are experienced by the subassembly or the extension tube, consequent deflections of the support springs on the elevator assembly actuate elevator-arm limit switches. These switches prevent or stop operation of the reactor-vessel cover drive, the control-rod-drive lifting platform, or the subassembly drive mechanism, depending on the mode of operation in effect at that time. Limit switches on the force-transducer-readout instrument will be set to provide advance warning of approaching overload conditions. 


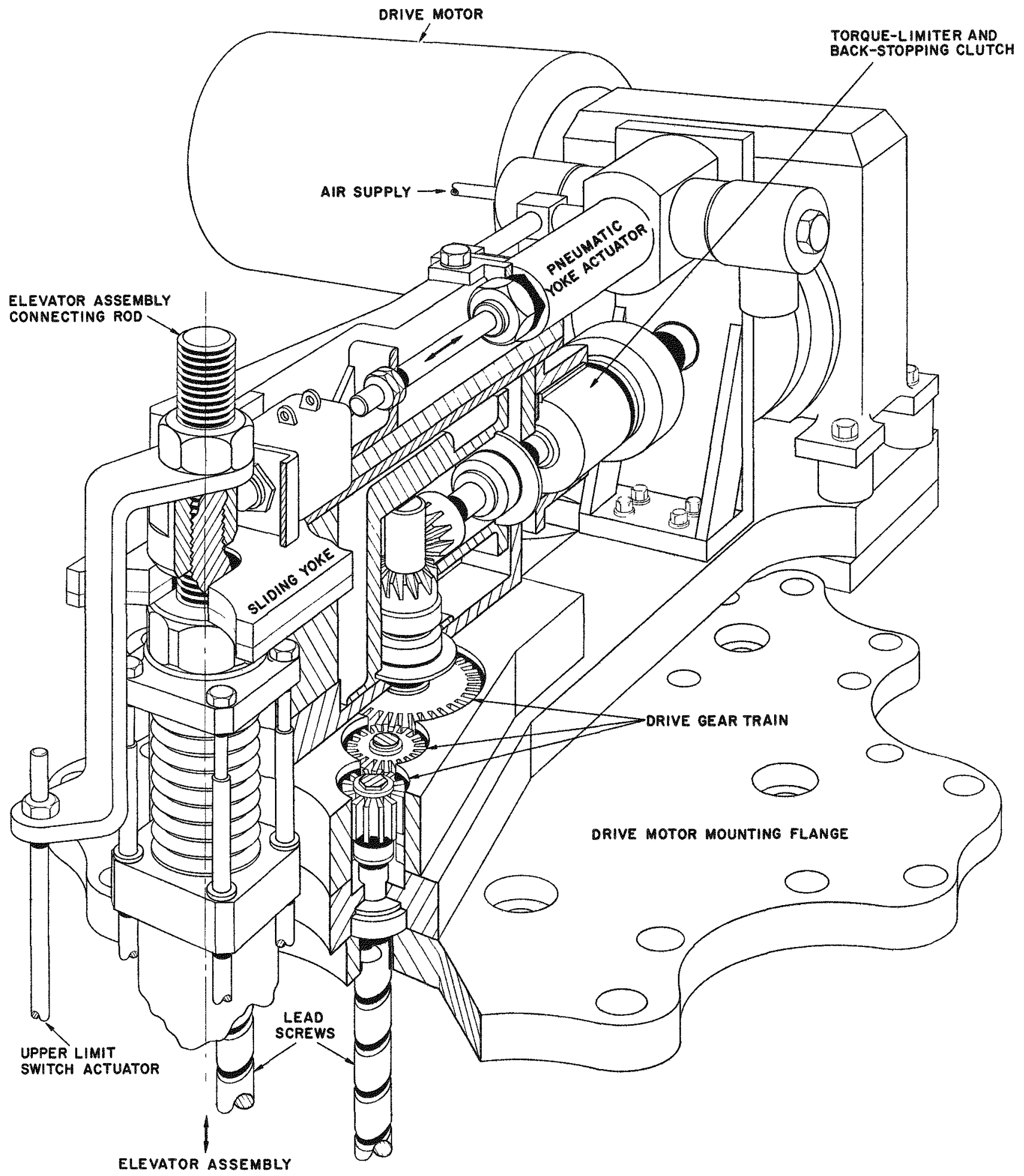

Fig. 11. Drive Motor-Gear Train-Lead Screw Assembly for Effecting Vertical Travel of Elevator Assembly. A lso shown is the "full-up" interlock in the engaged position. 


\section{SUPPORTING RESEARCH AND DEVELOPMENT}

Supporting research and development are focussed on the selection and verification of candidate components for inclusion in the instrumented subassembly system. Items of greatest concern, i.e., lead severance, subassemblyto-extension-tube coupling, and lead-brazing operations, are in the final stages of development. Exploratory tests in support of the selected design features and components as well as proposed full-scale mockup tests of an integrated assembly are summarized in the following subsections.

\section{A. Lead Severance}

Laboratory tests on mockups of various axial and rotary cutter concepts in room-temperature air and in $700^{\circ} \mathrm{F}$ sodium have led to selection of a rotary cutter for severing instrument wires and tubes that lead from the subassembly upper adapter.

Basically, the cutter consists of two diametrically opposed blades machined on the periphery of a hollow shaft of tool steel (AISI-SAE-TI) hardened to Rockwell C.58. This shaft slips over and rotates a round the subassembly top end fixture, which acts as a cutting guide. The cutting operation is actually a shearing process, which is effected with a nominal amount of torque that can be applied either manually or with a motor drive.

Initial room-temperature tests were made on a mockup assembly enclosed in transparent plastic. The objective was to observe the constraint of limited space on cutting of lead wires and tubes positioned in a simulated upper adapter. Approximately 330 stainless steel-sheathed, 1/16- and 1/8-in.-OD alumina oxide-insulated leads and 0,188-in.-OD, 0.016-in.-wall stainless steel tubes were cut. As a result of these tests, the cutting angle of the blades was increased from 0 to $15^{\circ}$ to impart a side thrust to each severed lead or tube and prevent their interference with unsevered units.

The modified cutter was then tested in a mockup designed to simulate, as closely as possible, the instrumented subassembly and the operating environment. The objective was to determine the amount of torque required to sever similar tubes and lead wires of various diameters exposed to the sodium coolant at shutdown temperature $\left(700^{\circ} \mathrm{F}\right)$.

The results of these tests are tabulated below; also listed are the corresponding torques required to effect severance in room-temperature air.

\begin{tabular}{|c|c|c|c|c|}
\hline \multirow[b]{2}{*}{ Specimen } & \multirow[b]{2}{*}{ Diam, in. } & \multirow{2}{*}{$\begin{array}{l}\text { No. } \\
\text { Cut }\end{array}$} & \multicolumn{2}{|c|}{ Torque, ft-lb } \\
\hline & & & Sodium & Air \\
\hline Lead wires & $1 / 16$ & 204 & 8 & 11 \\
\hline Lead wires & $1 / 8$ & 60 & 18 & 24 \\
\hline Tubes & $3 / 16^{*}$ & 12 & 15 & 21 \\
\hline
\end{tabular}

*0.016-in. wall. 
Severance was accomplished more readily in sodium because of the decreased yield strength of the stainless steel sheath material at $700^{\circ} \mathrm{F}$. All cuts were sharp and clean, leaving no metal chips. The AISI-SAE-Tl blades remained keen, with no change in hardness despite the 12 thermal cycles (from 70 to $700^{\circ} \mathrm{F}$ ) incurred during startup and shutdown for each series of tests.

\section{B. Assembly and Brazing of Instrument Leads}

Because of the limited space for maknng lead penetrations, induction brazing has been selected as the method of retaining and sealing instrument leads in the drywell bulkhead. In addition, a procedure has been established whereby all leads are properlyoriented within the upper adapter and bulkhead and brazed simultaneously. The basic sequence of operations is as follows.

At the outset, removable Teflon indexing tabs are used to properly orient leads from the subassembly while they are threaded through the upper adapter into the drywell bulkhead. Lead threading is accomplished with the aid of a screw-driven cradle that moves the subassembly axially into a stationary upper adapter

Prior to brazing operations, the bulkhead and the leads passing through it a re cleaned by induction heating in a pure hydrogen atmosphere at $2120^{\circ} \mathrm{F}$. Subsequently, the bulkhead is cooled to room temperature, and the brazing compound is applied in powder form. This compound is a high-nickel alloy (GE-81), which has a meltung point of $2075^{\circ} \mathrm{F}$. The assembly is then preheated and allowed to soak in pure hydrogen before being heated to the melting temperature of the braze. Figure 12 shows a typical microstructure of the leaktight braze achieved using this procedure.

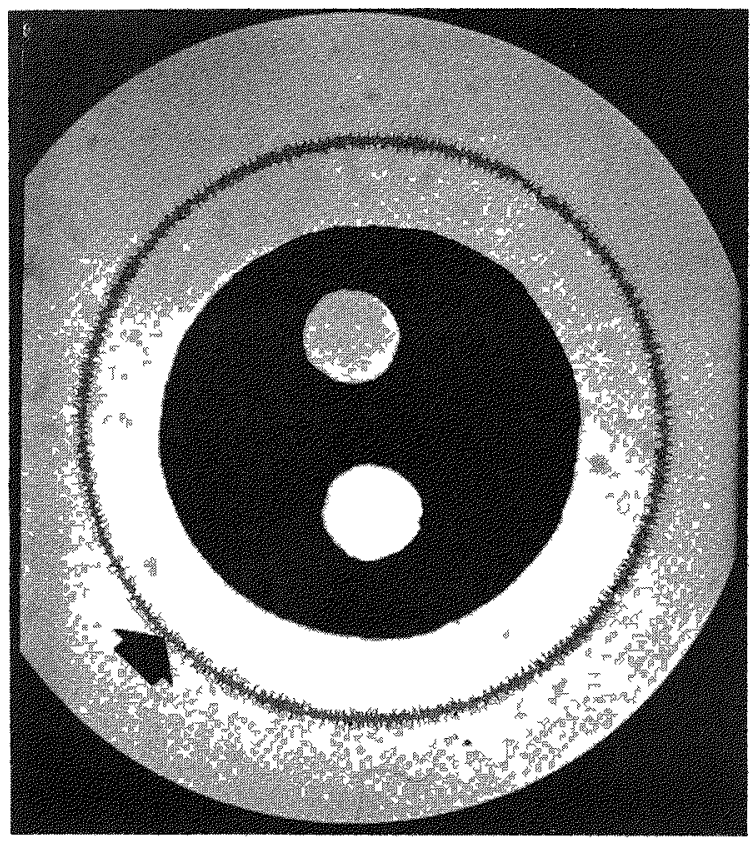

Fig. 12

Microstructure of Braze between Type 304 Stanless Steel-sheathed Thermocouple and Penetration in Type 304 Drywell Bulkhead. Arrow points to sound braze between Type 304 stainless steel-sheathed thermocouple and penetration in Type 304 dry well bulkhead. 
C. Coupling of Subassembly and Extension Tube

Numerous coupling concepts (bayonet, threaded, welded) have been evaluated, with emphasis on simplicity of engagement and disengagement, strength characteristics, and degree of obstruction to leads within the subassembly and to fuel-handling equipment and procedures.

For example, two bayonet-type couplings were considered: one using a conventional bayonet lug arrangement, the other interlocking a hexagonal sleeve over the hexagonal upper adapter. Although inherently strong designs, both were rejected because they required rotational and axial movements to effect engagement and disengagement.

As described earlier, the mode of coupling selected consists of four jaws, which enclose the subassembly upper adapter, and a sleeve, which retains the jaws in the engaged position. This method of coupling leaves the upper adapter free from obstructions and allows moxe space for leads and coolant flow channels. Uncoupling is effected with a single upward motion of the locking sleeve, allowing the jaws to spread and release the upper adapter. Resistance to bending and torsional loads during lead severance is accomplished by mating the hexagonal subassembly upper adapter with a sleeve of similar geometry on the extension-tube bottom.

Tensile, bend, and torsion tests were performed successfully on a full-scale model of the coupling in room-temperature air. The tensile test consisted of loading the coupling up to $3000 \mathrm{lb}$. This load corresponds to the strength of standard core subassemblies. ${ }^{3}$ In the bend test, a moment of $2500 \mathrm{lb}$-in. was applied. This moment corresponds to the unsupported horizontal weight of the subassembly acting on the coupling. Moments of this order are far in excess of the negligible inertial and sodium drag loads that will be imposed on the withdrawn subassembly each time the small and large rotating plugs are repositioned during normal fuel-handling operations. A torsional load of $200 \mathrm{ft}-1 \mathrm{~b}$ was applied to ascertain the margin for resisting lead-cutting torques. (See tabulation on p. 28.) In all tests, when the load was released to zero, the coupling returned to its original configuration, indicating elastic behavior.

Coupling and uncoupling tests also were performed in $700^{\circ} \mathrm{F}$ sodium to determine the vertical force required to release the jaws and the effect of misalignment on uncoupling. Results indicated that a force of $10 \mathrm{lb}$ was required and that a misalignment of $1 / 16$ in. had no effect on uncoupling.

D. Full-scale Mockup Test Facility

Figure 13 shows the out-of-pile test facility designed to evaluate both the performance characteristics of candidate components and an integrated, full-scale instrumented subassembly and extension tube. The scope of the tests"includes uncoupling procedures, lead severance operations, and simulated extension tube-cutting assembly removal techniques. 


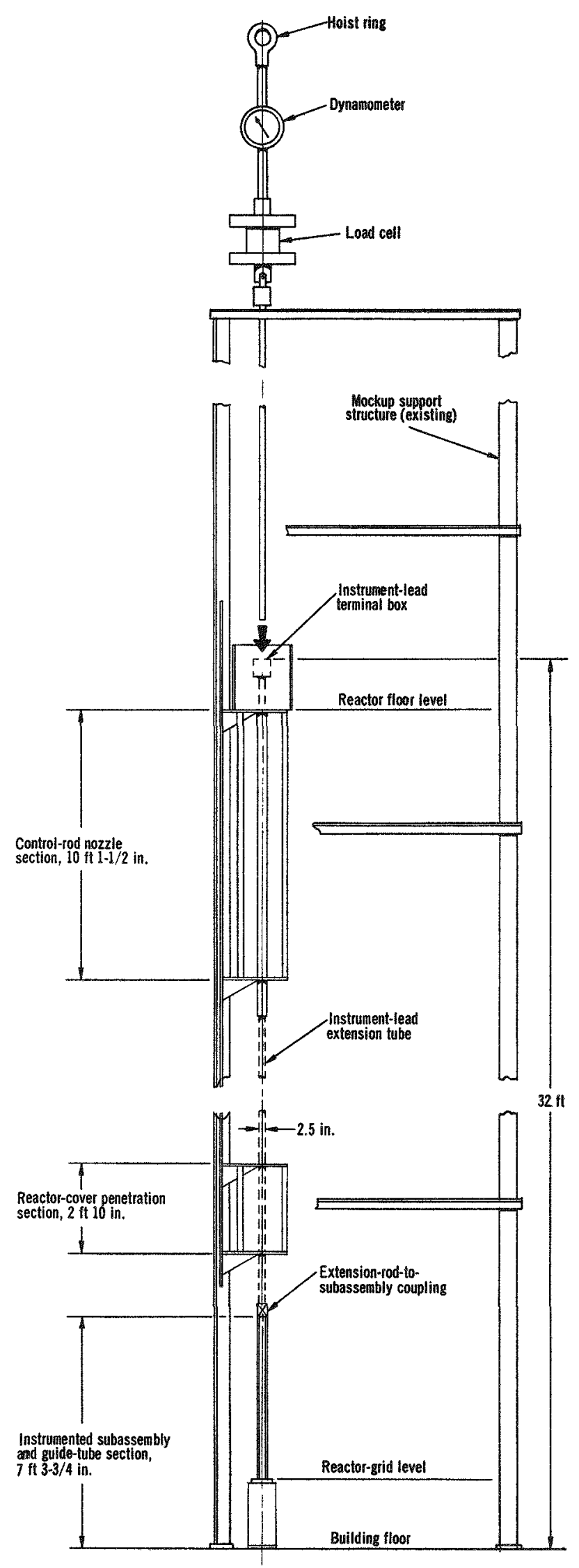

Fig. 13

Full-scale Mockup Test Facility for Evaluating Performance of Independent and Integrated Components of Instrumented Subassembly System 


\section{PROTOTYPE INSTRUMENTED SUBASSEMBLY}

\section{A. Objectives}

Concurrent effort is being directed toward early installation (about January 1969) of a prototype instrumented subassembly into the EBR-II. The objectives here are: (1) to demonstrate the engineering feasibility of such an installation; (2) to assess the unique aspects of the system compo. nents, their compactness, and their effects on overall operation of the reactor: (3) to evaluate the performance of candidate sensors, metering devices, and lead wires in a high-temperature, fast neutron flux and sodium environment; (4) to identify existing or potential problems associated with long-term exposure of instrumented fuel subassemblies in liquid-metalcooled fast breeder reactors; and (5) to accumulate data basic to the design and installation of similarly instrumented subassemblies in the Fast Flux Test Facility and future LMFBRs currently under development.

\section{B. Reference Design Criteria}

Table I lists the reference design criteria established for the prototype instrumented subassembly and includes alternative design characteristics for subsequent subassemblies. Some of these characteristics may be incorporated at the option of the experimenter. Others are contingent upon reactor operation at a higher power level or, for multiple installations, are subject to development of control rods of increased reactivity worth.

\section{Nature of Instrumentation}

Instrumentation of an irradiation test subassembly may be classim fied into two basic categories:

(1) Instruments that monitor gross environmental conditions within the subassembly such as neutron flux, coolant flow, temperature, and pressure. These may be designed as an integral part of the subassembly, e.g., flowmeter.

(2) Instruments that provide behavioral data on capsulated materials or material assemblies exposed to the environmental conditions. The nature of these instruments will vary with individual experiments. Typical examples are fuel and cladding thermocouples and fission-gas pressure transducers.

Consistent with the anticipated scope of sensing and metering devices to be installed in subsequent subassemblies, the prototype subassembly has been designed to accommodate a variety of irradiation test capsules, instrumentation, and lead-wire assemblies. The selection is not all-inclusive; rather it reflects the current status of in-core instrumentation and capsule development. 
TABLE I. Reference and Alternative Design Criteria for Instrumented Subassembly Installations in EBR-II

\begin{tabular}{|c|c|c|}
\hline & Prototype & Alternatives \\
\hline \multicolumn{3}{|l|}{ Subassembly } \\
\hline Number & 1 & $4(\max )^{a, b}$ \\
\hline Location (control-rod position) & No. 6 & $\begin{array}{l}\text { Nos. 2, 6, 8, and 10; or Nos. 2, } 6 \text {, } \\
8 \text {, and } 11^{\mathrm{a}, \mathrm{b}}\end{array}$ \\
\hline Configuration & Hex. tube & Hex. tube \\
\hline Material & 304 SS & 304 SS \\
\hline \multicolumn{3}{|l|}{ Dimensions, in. } \\
\hline $\begin{array}{l}\text { Across flats } \\
\text { Inside flats } \\
\text { Overall length } \\
\text { Less lead length } \\
\text { Inc. } 24-1 / 4 \text {-in. lead }\end{array}$ & $\begin{array}{l}1.902 / 1.912 \\
1.824 / 1.830 \\
93-37 / 64 \\
112-7 / 32\end{array}$ & $\begin{array}{l}1.902 / 1.912 \\
1.824 / 1.830 \\
\\
93-37 / 64 \\
112-7 / 32\end{array}$ \\
\hline \multicolumn{3}{|l|}{ Capsule } \\
\hline $\begin{array}{l}\text { Number per subassembly } \\
\text { Material } \\
\text { Dimensions, in. } \\
\text { Diameter } \\
\text { Wall thickness } \\
\text { Length } \\
\text { Spacer Wire } \\
\text { Material } \\
\text { Diameter, in. }\end{array}$ & $\begin{array}{l}18 \\
304 \text { SS } \\
0.357 \pm 0.0010 \\
0.020 \\
40 \\
304 \text { SS } \\
0.041 \pm 0.0005\end{array}$ & $\begin{array}{l}18,19,36,37^{\mathrm{a}} \\
304 \mathrm{SS} \\
\leq 0.357^{\mathrm{a}} \\
40 \\
304 \mathrm{SS} \\
\mathrm{a}\end{array}$ \\
\hline \multicolumn{3}{|l|}{ Element } \\
\hline $\begin{array}{l}\text { Cladding } \\
\text { Material } \\
\text { Dimensions, in. } \\
\text { Diameter } \\
\text { Wall thickness } \\
\text { Length }\end{array}$ & $\begin{array}{l}304 \text { SS } \\
0.290 \\
0.020 \\
27.3\end{array}$ & $\begin{array}{l}304 \text { SS } \\
\text { a } \\
\text { a } \\
\text { a }\end{array}$ \\
\hline $\begin{array}{l}\text { Fuel } \\
\text { Material } \\
\text { Est. } 235 \mathrm{U} \text { enrichment, \% } \\
\text { Method of fabrication } \\
\text { Dimensions, in. } \\
\text { Diameter } \\
\text { Length } \\
\text { Theoretical density. \% }\end{array}$ & $\begin{array}{l}\text { U02 } \\
65 \\
\text { Vipac and sintered } \\
0.247 \\
14.22 \\
85-90\end{array}$ & $\begin{array}{l}\mathrm{a} \\
\mathrm{a} \\
\mathrm{a} \\
\mathrm{a} \\
\mathrm{a} \\
\mathrm{a}\end{array}$ \\
\hline Neutron flux, $\mathrm{n} /\left(\mathrm{cm}^{2}\right)(\mathrm{sec})$ & $2 \times 10^{15}$ & $2 \times 10^{15 C}$ \\
\hline Power output, kW & 270 & a \\
\hline Coolant temperature at inlet, ${ }^{\circ} \mathrm{F}$ & 700 & 700 \\
\hline Flowrate through subassembly, gpm & $59 d$ & $\sim 60 \max d$ \\
\hline Coolant temperature rise, ${ }^{\circ} \mathrm{F}$ & 200 & $200 \mathrm{C}$ \\
\hline Vertical travel for fuel handling, in. & 96 & 96 \\
\hline Speed of travel for fuel handling, in./min & 15 & 15 \\
\hline \multicolumn{3}{|l|}{ Extension tube } \\
\hline Material & 304 SS & 304 SS \\
\hline Diameter (nominal), in. & 2.5 & 2.5 \\
\hline Wall thickness (nominal), in. & 0.120 & 0.120 \\
\hline Overall length (subassembly, extension tube, terminal box), ft & 36 & 36 \\
\hline Estimated total weight, Ib & $\sim 300$ & $\sim 300$ \\
\hline No. of leads & 23 & a \\
\hline No. of signals & 26 & a \\
\hline
\end{tabular}

asubject to user's requirements or option.

bWith eight control rods of increased reactivity worth.
CMay be higher with future increase in reactor power level.

See Section IV.D for reference heat-transfer and fluid-flow data. 
More specifically, the subassembly will be equipped with one inletcoolant thermocouple, three outlet-coolant thermocouples, one flowmeter, and one 3/16-in.-diam tube for future flux monitors. The internal structure will be capable of accommodating nineteen 0.357 -in.-OD, 40-in.-long capsules. Heat generated in these capsules will be removed by the primary sodium coolant flowing through the capsule array in parallel with flow through adjacent core subassemblies.

Eighteen capsules will be installed; sixteen will be loaded with clad uranium oxide fuel elernents and a sodium thermal bond, two with structural materials. The 19th position will house a sheathed lead conduit. Three of the fuel capsules will be equipped with fuel centerline thermocouples, four with both fuel centerline and cladding thermocouples, and four with fissiongas-pressure transducers. Five fuel capsules will not be instrumented per se, but two will be used to support outlet coolant thermocouples. Centerline thermocouples will be installed in the two capsules containing structural materials.

Table II lists the pertinent design characteristics of the lead assemblies to be used with these instruments.

TABLE II. Design Characteristics of Instrument-lead Assemblies for Prototype Subassembly

\begin{tabular}{|c|c|c|c|c|c|c|c|c|c|}
\hline & \multirow{2}{*}{\multicolumn{3}{|c|}{ Conductors }} & \multicolumn{4}{|c|}{ Sheath or Tube } & \multicolumn{2}{|c|}{ Hole Diam, in. } \\
\hline & & & & \multirow{2}{*}{$\begin{array}{l}\text { Electrical } \\
\text { Insulation }\end{array}$} & \multirow[b]{2}{*}{ Material } & \multirow{2}{*}{$\begin{array}{l}\text { op, in. } \\
\left(\begin{array}{r}+0.000 \\
-0.001\end{array}\right)\end{array}$} & \multirow{2}{*}{$\begin{array}{l}\text { Wall, } \\
\text { in. } \\
\text { (min) }\end{array}$} & \multirow{2}{*}{$\begin{array}{l}\text { Upper } \\
\text { Adapter } \\
( \pm 0.001)\end{array}$} & \multirow{2}{*}{$\begin{array}{l}\text { Bulkhead } \\
( \pm 0.0005)\end{array}$} \\
\hline & No. & Diam, in. & Material & & & & & & \\
\hline Flowmeter & 2 & 0.020 & 304 SS & Alumina & 304 SS & 0.125 & 0.012 & 0.136 & 0.127 \\
\hline \multicolumn{10}{|l|}{ Pressure transducer } \\
\hline Tube & - & - & - & - & 304 SS & 0.125 & 0.012 & 0.136 & 0.127 \\
\hline $\begin{array}{l}\text { Thermocouple } \\
\text { Integral lead }\end{array}$ & 2 & 0.010 & Chromel/Alumel & Alumina & 304 SS & 0.0625 & 0.009 & - & $0.0645^{a}$ \\
\hline $\begin{array}{l}\text { Coolant thermocouple } \\
\text { Lead }\end{array}$ & 2 & 0.010 & Chromel/Alumel & Alumina & 304 SS & 0.0625 & 0.009 & 0.070 & 0.0645 \\
\hline Fuel cladding thermocouple & 2 & 0.0065 & Chromel/Alumel & Alumina & 304 SS & $0.040^{b}$ & 0.006 & 0.070 & 0.0645 \\
\hline Integral lead & 2 & 0.010 & Chromel/Alumel & Alumina & 304 SS & 0.0625 & 0.009 & 0.070 & 0.0645 \\
\hline Fuel thermocouple & 2 & 0.010 & $W-3 \% \operatorname{Re} / W-25 \% \operatorname{Re}$ & Thoria & Tantalum & 0.0625 & 0.009 & - & - \\
\hline Lead & 2 & 0.010 & 308 ELC SS/Alumel & Alumina & 304 SS & 0.0625 & 0.009 & 0.070 & 0.0645 \\
\hline Flux monitor tube & - & - & - & - & 304 SS & 0.1875 & 0.015 & 0.196 & 0.0190 \\
\hline
\end{tabular}

aln T fitting.

b Tolerance $= \pm 0.001$ in.

\section{Fuel-centerline Temperatures}

The fuel-centerline temperatures will be monitored by thermocouples having $\mathrm{W}-3 \% \mathrm{Re} / \mathrm{W}-25 \%$ Re thermoelements, thoria insulation, and tantalum sheaths. In-pile experience with this type of assembly is limited; however, it should furnish useful data for fuel temperatures below $2400^{\circ} \mathrm{C}$. Fuel enrichments will be adjusted to achieve centerline temperatures in the range $1800-2400^{\circ} \mathrm{C}$. Figure $14(\mathrm{a})$ shows the proposed method of installing the thermocouples in four fuel capsules. 


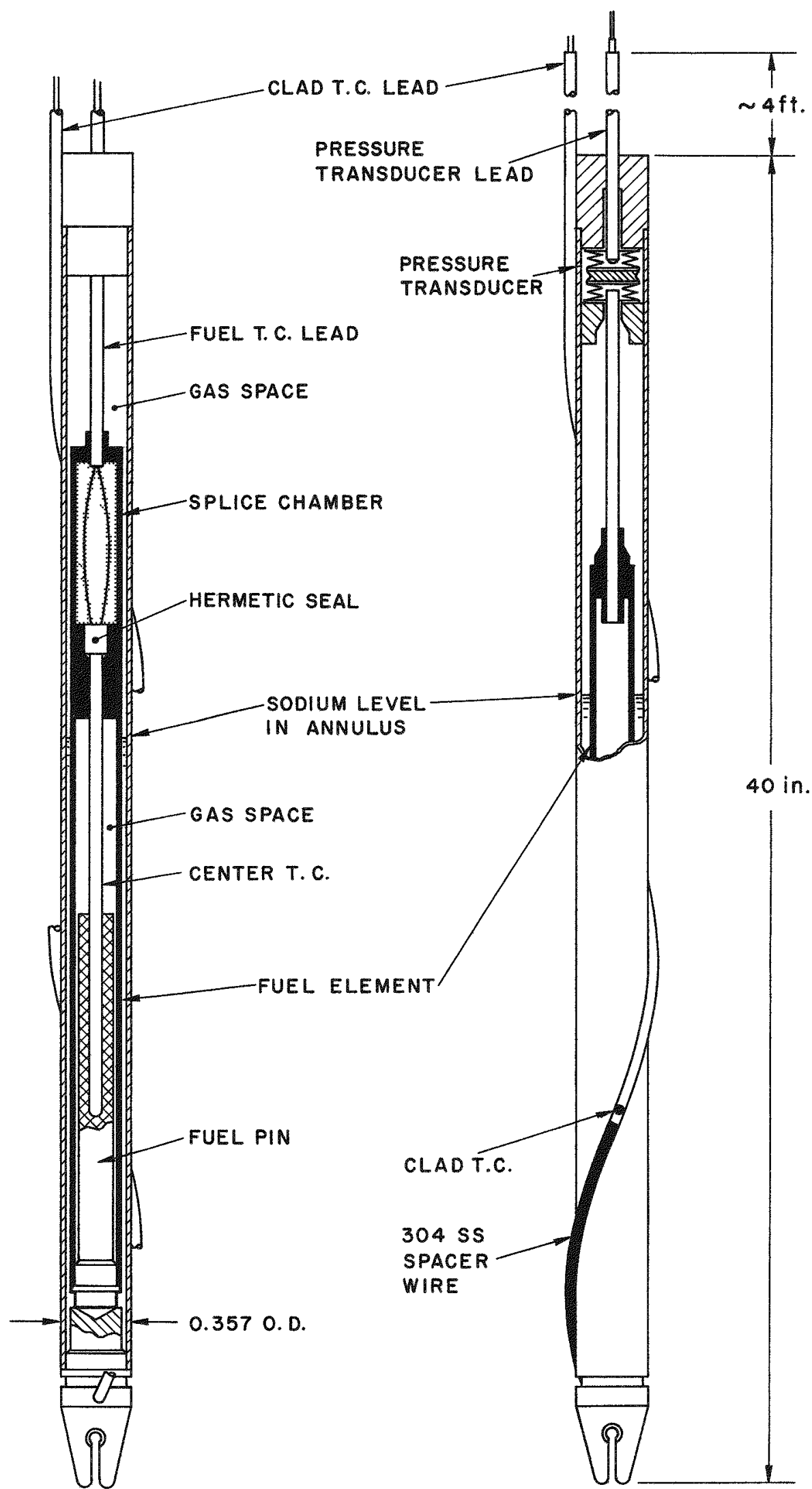

(a)

(b)

Fig. 14. Installation of Fuel and Cladding Thermocouples and Fission-gas Pressure Transducer in Irradiation Test Capsule 


\section{Fuel-cladding Temperatures}

The fuel-cladding temperatures will be monitored by four 0.0625-in.-diam thermocouples of swaged construction, with Chromel/ Alumel thermoelements, alumina insulation, and Type 304 stainless steel sheaths. As shown in Fig. 14(b), the lower portion of each thermocouple will be swáged to a 0.040 -in. diameter, attached to the wall of, and replace, the spacer wire (above the hot junction) around each capsule instrumented for fuel-centerline temperature measurements. The upper portion of the thermocouples will lead from atop the capsules to junctions with flexible lead wires above the bulkhead.

\section{Fission-gas Pressures}

Fission-gas pressures will be measured by a null-balance-type pressure-transducer system installed above the gas space in each fuelbearing capsule. This system uses a reference gas for signal output, which may be read directly on a gauge or, via a strain-gauge pressure transducer, on a millivolt recorder.

As shown in Fig. 14(b), each transducer consists of two vertical bellows, the inner ends of which are coupled to a thick-walled disc; the outer ends are welded to the capsule wall. The reference-gas pressure is controlled by signals generated upon contact between the coupling disc and a sheathed two-wire lead 0.0025 in. above the disc. This lead runs coaxially with the reference-gas supply line up through the bulkhead and into the dry well. Here they are separated by a connector fitting, as shown in Fig. 5.

In operation, the fission-gas pressure forces the coupling disc up to contact the lead and complete the electrical circuit. This circuit energizes a solenoid valve in the reference-gas supply line, which allows the gas in the bellows to pressurize ( 0.25 psig higher than the fission-gas pressure), force the coupling disc down, and open the circuit. At this point, the valve is de-energized to complete the cycle.

The coupling disc will be coated with gold to reduce possible oxidation and enhance electrical contact with the lead wire. If of interest to the experiment, the two-wire lead may be used as a thermocouple to measure the temperature at contact.

\section{Coolant Temperatures}

All coolant thermocouples will be of swaged construction, with Chromel/Alumel thermoelements, alumina insulation, and Type 304 stainless steel sheaths. This type of thermocouple has performed reliably in environments similar to those of the EBR-II core region. 
Subas sembly inlet-coolant temperatures will be monitored by a thermocouple of uniform 0.0625-in. diameter attached to the lower end of the lead conduit in the 19 th capsule position. This thermocouple will extend up through the conduit to a point above the bulkhead, where it will be attached to flexible Chromel/Alumel lead wires. Outlet-coolant temperature will be monitored by an identical thermocouple attached to the upper end of the conduit.

Two additional outlet-coolant thermocouples of similar diameter will be attached to extensions of the two noninstrumented capsules and extend up through the gripper adapter and the bulkhead. To achieve a fast time response, each thermocouple will be swaged to a 0.040 -in. diameter at the point of measurement.

\section{Coolant Flowrates}

A permanent-magnet-type (PM) flowmeter has been selected to sense coolant flowrates in the prototype subassembly. This selection was based upon successful operation of a similar unit for over $2000 \mathrm{hr}$ up to $1000^{\circ} \mathrm{F} \cdot{ }^{4,5}$

The following design criteria have been established:

$\begin{array}{ll}\text { Geometry } & \text { Hexagonal } \\ \text { Distance across flats, in. } & 1.728 \\ \text { Overall length, in. } & 9.188 \\ \text { Flow conduit ID, in. } & 0.625 \\ \text { Maximum flowrate, gpm } & 60 \\ \text { Pressure drop at max flowrate, psi } & 8.9 \\ \text { Integral extension lead wire } & \\ \quad \text { Wire size } & 24 \mathrm{AWG} \\ \text { Wire length, in. } & 82 \\ \text { Sheath diameter, in. } & 0.125\end{array}$

The magnetic circuit provides a fairly uniform field within the flow conduit and minimizes end effects. With reference to Fig. 15, the magnetic field is produced by two Alnico- 5 magnets operating in parallel. The pole pieces are fully annealed soft iron. The electrodes and the extension lead wires are fabricated of Type 304 stainless steel to minimize thermoelectric and thermal-expansion effects; they are insulated with high-purity alumina. It is planned to backfill the flowmeter with helium (through the evacuation tube) to prevent initial corrosion of the pole pieces and magnets, and to provide a medium for removal of gamma heat generated in these components.

Operation of a PM flowmeter is similar, in principle, to that of a dc generator. As the conducting liquid (sodium) flows through a tube 


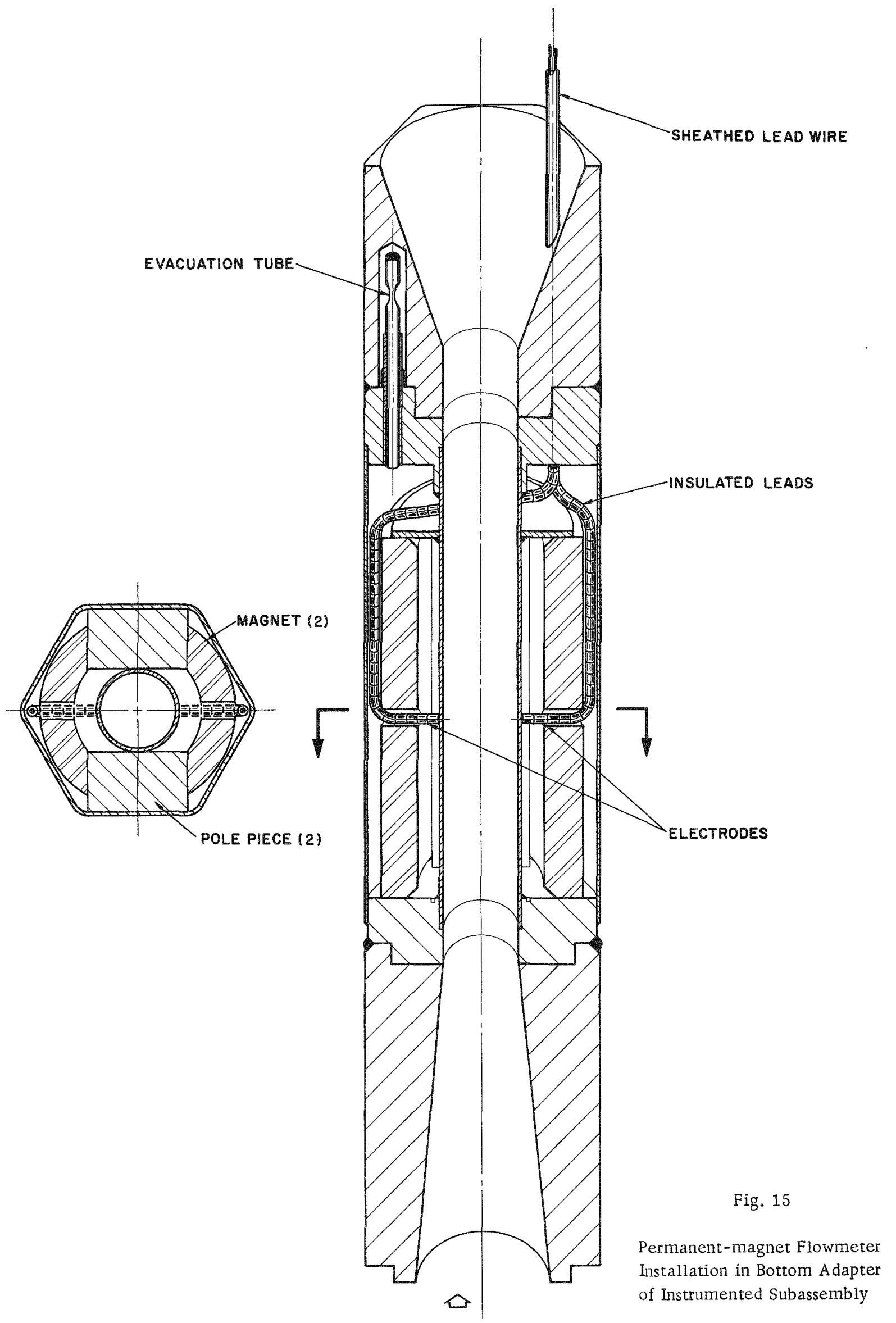


positioned in a stable magnetic field, a potential is developed across the tube and at right angles to the field. This potential is proportional to the volumetric flowrate of the liquid and the magnetic flux density.

Flowmeter sensitivity (in $\mathrm{mV} / \mathrm{gpm}$ ) is given by the relation

$$
S=\frac{E}{Q}=\frac{3.17 \mathrm{~K}_{\mathrm{TB}}\left(10^{-4}\right)}{\mathrm{d}}
$$

where

$$
\begin{aligned}
E & =\text { measured output, } \mathrm{mV}, \\
\mathrm{Q} & =\text { flowrate, gpm, } \\
\mathrm{K}_{\mathrm{T}} & =\text { correction factor for end effects, temperature effects, etc., } \\
\mathrm{B} & =\text { magnetic-flux density, Gauss, }
\end{aligned}
$$

and

$$
\mathrm{d}=\text { ID of flow conduit, in. }
$$

Accordingly, based upon the expected magnetic-flux density and conduit inside diameter, a sensitivity of $0.325 \mathrm{mV} / \mathrm{gpm}$ is anticipated at a sodium temperature of $800^{\circ} \mathrm{F}$, or about $19.5 \mathrm{mV}$ output at the maximum flowrate $(60 \mathrm{gpm})$.

D. Calculated Hydraulic Characteristics

Fluid-flow calculations were made on the prototype subassembly, using the reference parameters and the capsule and flowmeter dimensions listed in Table III.

TABLE III. Criteria Used in Hydraulic Analysis of Prototype Instrumented. Subassembly

Subassembly

Geometry

Distance across flats, in.

Length, in.

Capsules

Number of positions

Diameter, in.

Length, in.

Spacer wire diameter, in.
Hexagonal tube

1.824

$93 \frac{37}{64}$

19

0.359

40

0.040

Flowmeter

Conduit ID, in.

0.625

Conduit length, in. 
Figure 16 shows the estimated total pressure drop as a function of sodium flowrate through the subassembly with and without a flowmeter. The total $\triangle \mathrm{P}$ without a flowmeter consists of the following components:

$\triangle \mathrm{P}_{1}$ : entrance losses through six orifices in the lower adapter.

$\triangle \mathrm{P}_{2}$ : entrance loss to capsule bundle.

$\triangle P_{3}$ : exit loss from capsule bundle.

$\triangle \mathrm{P}_{4}$ : friction loss through capsule bundle.

$\triangle P_{5}$ : entrance loss to upper adapter.

$\triangle P_{6}$ : friction loss through upper adapter.

$\triangle P_{7}$ : exit loss from upper adapter.

$\triangle P_{8}$ : friction loss through extension tube.

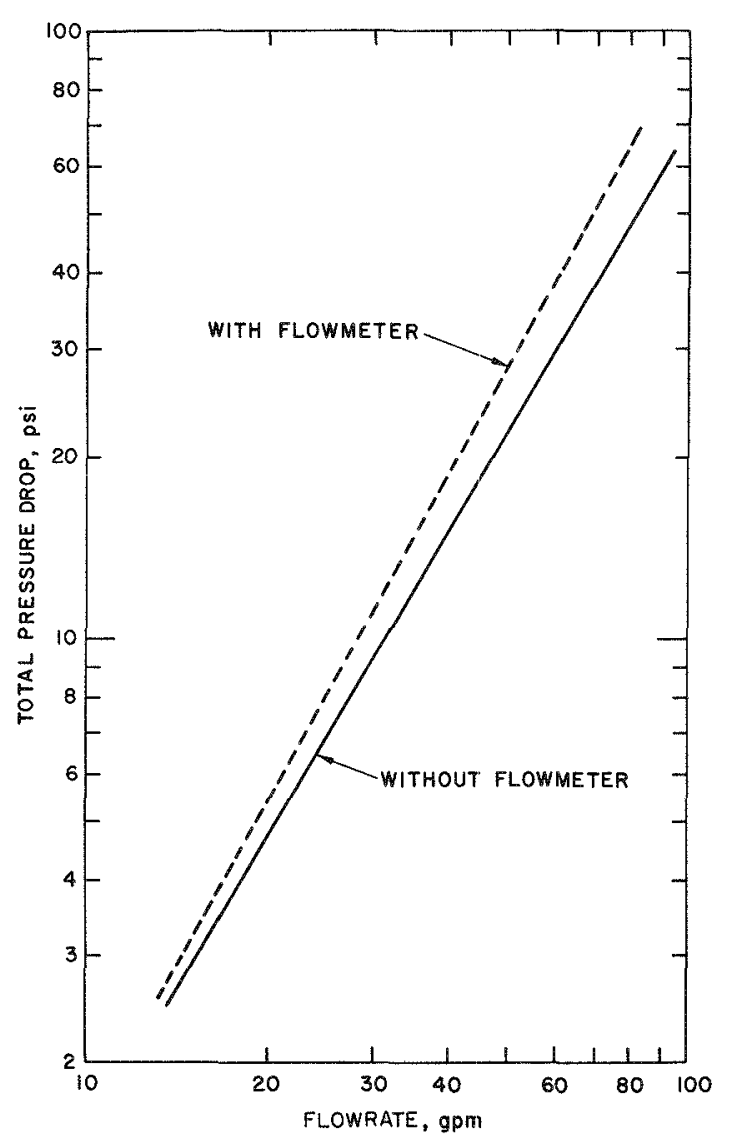

Fig. 16. Calculated Total Pressure Drop in Prototype Instrumented Subassembly with and without Flowmeter
The lower adapter of the prototype instrumented subassembly is essentially identical to that of a standard control subassembly. Therefore, the calculated pressure drop in this region of the prototype subassembly was checked against the value determined by previous water-loop tests on a standard subassembly. The results were in good agreement.

With a flowmeter installed and with a total effective pressure drop of 38.8 psi between the inlet and outlet plenums, * the maximum sodium flowrate was calculated to be about $59 \mathrm{gpm}$. At this flowrate and a corresponding temperature rise of $200^{\circ} \mathrm{F}$, the maximum rate of heat transfer is $1.53 \times 10^{6} \mathrm{Btu} / \mathrm{hr}$.

The foregoing calculations will be checked against values determined from water flow tests on a mockup subassembly.

Additional calculations were made to determine the sodium velocity and flow distribution in channels

formed by the capsule array. With reference to the analytical models used (Fig. 17), it was assumed that equal pressure drops occur in the central,

*Used for flow computations of control subassemblies. 
side, and corner channels, and that the flow is turbulent in all channels. Accordingly, the accompanying tabulation shows the corresponding calculated velocities and flow distributions expressed as percentages of the average flow through the capsule array.

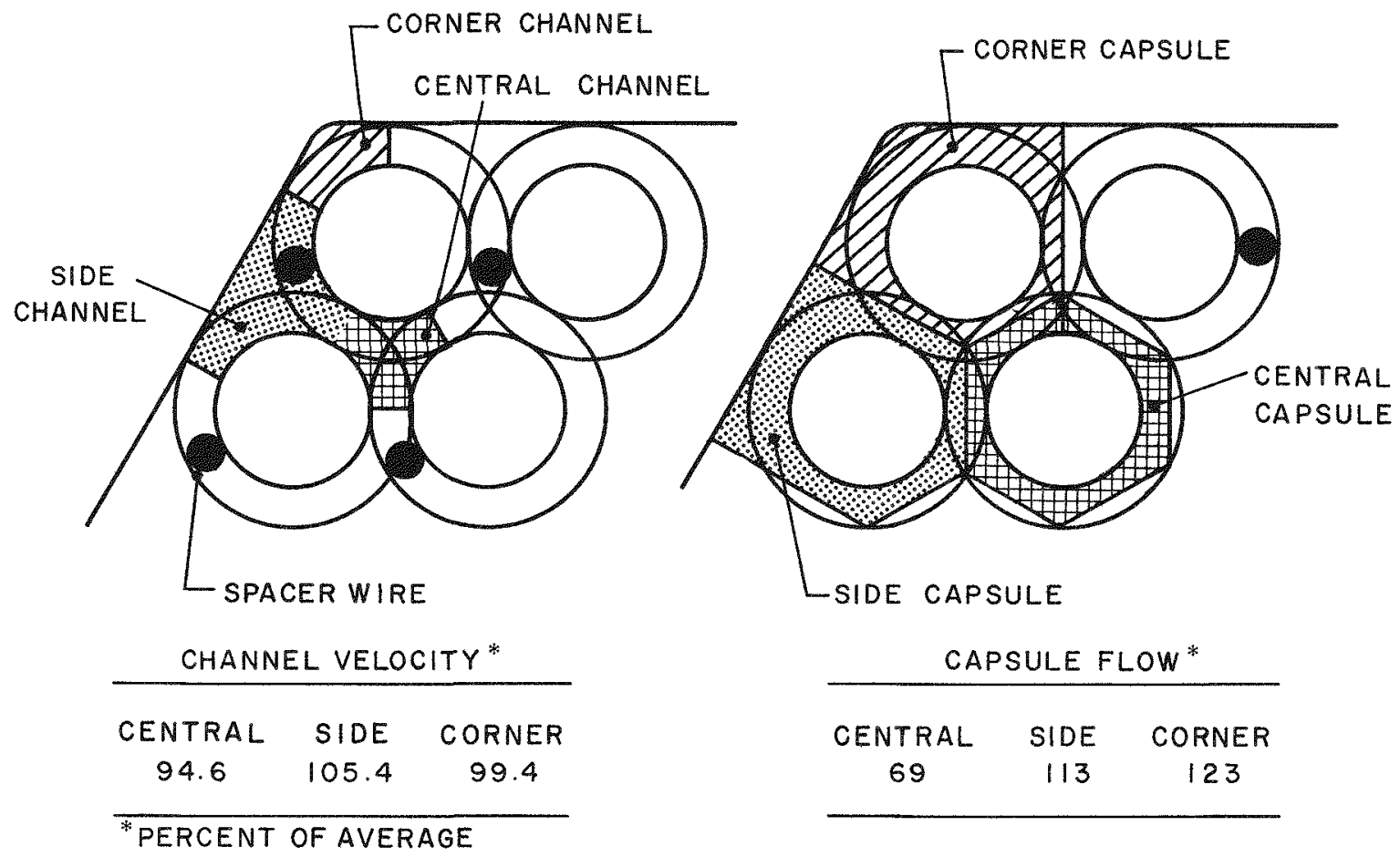

Fig. 17. Mathematical Models and Calculated Velocity and Flow Distribution in Instrumented Subassembly

E. Shipment, Installation, and Removal

1. Shipment

To expedite installation in the EBR-II reactor, the prototype instrumented subassembly, extension tube, and terminal box will be assembled, checked out, and shipped as an integrated unit. The unit (see Fig. 18) weighs $300 \mathrm{lb}$; it will be transported in a special container. This container features an inner structure which supports the subassembly rigidly in any position, and an outer structure which prevents shock loads from being transmitted to the subassembly during transport.

\section{Installation}

Upon arrival at the reactor site and before installation into the primary tank, the subassembly-extension-tube assembly will be thoroughly checked out. This checkout will include visual inspection, dimensional surveys, pressure tests of the integrated unit, and electrical tests of the instrument circuitry. 


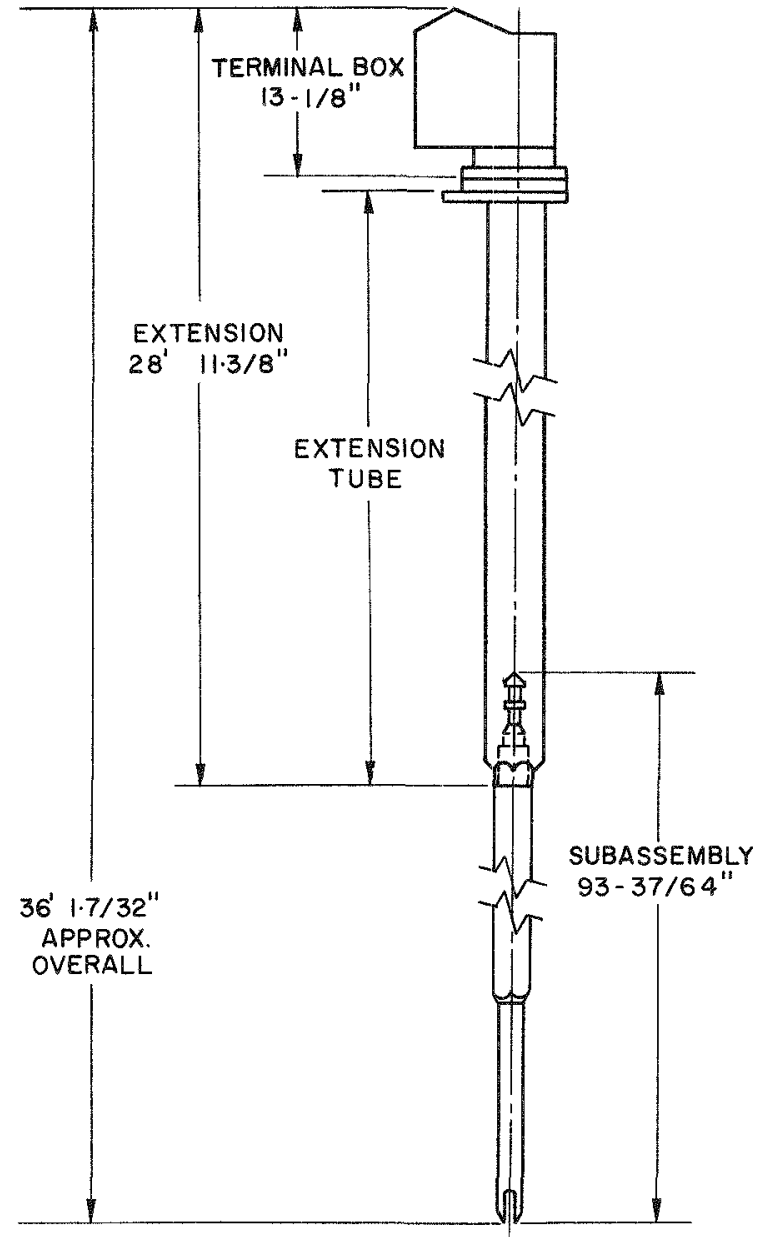

Fig. 18. Linear Dimensions of Integrated Prototype Unit to be Shipped to Reactor Site
During a scheduled reactor shutdown, the unit will be lowered through a vacated control-rod drive position in the rotating plug, into the corresponding position in the reactor vessel. This portion of the installation sequence will be accomplished by using established techniques and procedures for handling control-rod drive and fuel-handling components. The balance of the sequence will involve engagement of the bellows flange, extension tube, and electromechanical drive, and interconnections between the lead terminal box and readout instruments. Finally, a general functional checkout of the system will be made before reactor startup.

\section{Removal}

a. Basic Sequence. After reactor shutdown and preparatory to removal of the instrumented subassembly, the drive system and terminal box will be disconnected from the extension tube, and the tube separated from the subassembly. At this point,

the extension tube will be removed, through the rotating plug, into a pulling pipe for transport to a prescribed storage location in the reactor building.

The subassembly will be removed from the reactor and transferred by the existing fuel-handling mechanisms to the primary tank storage rack. After a 15-day decay period, the subassembly will be removed from the tank (through a fuel-loading port) by the fuel-handling machine, deposited into the interbuilding coffin, and transported to the air cell of the Fuel Cycle Facility for disassembly.

b. Separation of Extension Tube. This portion of the removal sequence involves three major operations:

(1) Uncoupling of the extension tube from the subassembly upper adapter, and removal of the coupling assembly.

(2) Insertion of the cutting assembly, and severance of the instrument leads and tubes.

(3) Removal of the extension tube and the cutting assembly. 
The coupling assembly is withdrawn from the extension tube and primary tank by using the pulling pipe and procedures employed for removing the control-rod drive shafts.

After the coupling assembly has been removed, the cutting assembly is lowered into the extension tube to sever the instrument leads. As shown in Fig. 19, the cutting assembly consists of a 1.5-in.-OD, 0.25-in.-wall, 29-ft-long hollow shaft, a retainer, a 0.5-in.-OD, 28.5-ftlong internal, freely supported sensing rod, and a cutter tool having two diametrally opposed, integral cutter blades. When fully inserted, the shaft is supported by the retainer at the top by the extension tube, the sensing rod contacts the conical end of the subassembly adapter, and the cutter tool is centrally positioned at the surface of the adapter (cutting plane). In operation, the shaft (and blades) is rotated $180^{\circ}$ to sever the instrument leads. A motor drive rotates the cutting assembly. During rotation, the armature current is recorded, providing a visual display of the cutting torque and sequence for each diametral pair of leads. Upon completion of this operation, the subassembly is detached, but is restrained from movement by the extension tube.

Final separation is effected upon removal of the extension tube and the contained cutting tool. During the first 6 in. of their upward travel, the sensing rod is held in contact with the subassembly adapter to ensure complete separation from the extension tube. Both the tube and the cutting tool are lifted partially through the rotating plug into the pulling pipe, allowed to drain and cool, and then completely withdrawn for transport to a storage location. A gate valve is installed to seal the vacated drive position pending removal of the instrumented subassembly.

As mentioned in Section a. above, the instrumented subassembly will be removed from the reactor to the air cell of the Fuel Cycle Facility, using existing fuel-handling procedures and equipment. If a fresh instrumented subassembly is not available for immediate installation in the reactor, a "dummy" assembly will be installed temporarily.

c. Dummy Assembly. The dummy assembly consists of two separate components: (1) a dummy control subassembly, which is loaded into the vacated guide thimble in the reactor vessel; and (2) a shield-plug assembly, which replaces the withdrawn extension tube. Both components are fabricated of Type 304 stainless steel.

With one exception (the lower adapter), the dummy subas sembly is identical in external configuration to a standard control subassembly. Internally, the core section of 61 pin-type fuel elements is replaced by solid Type 304 stainless steel counterparts. Existing fuelhandling equipment and procedures are used to load the subassembly into the reactor. Design and hydraulic characteristics of the lower adapter are 


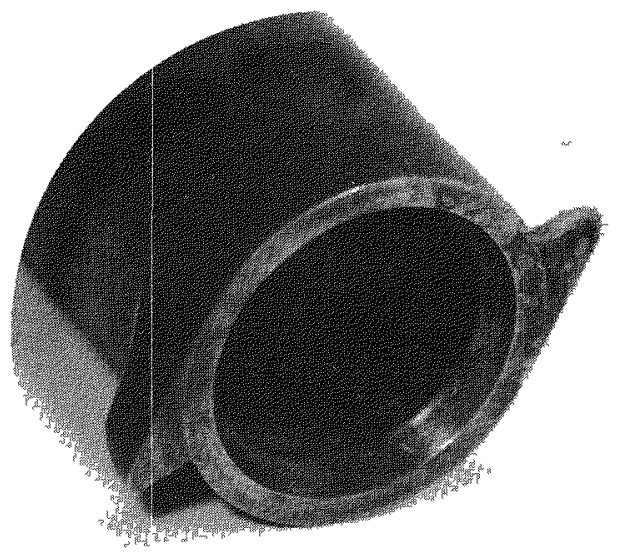

CUTTER

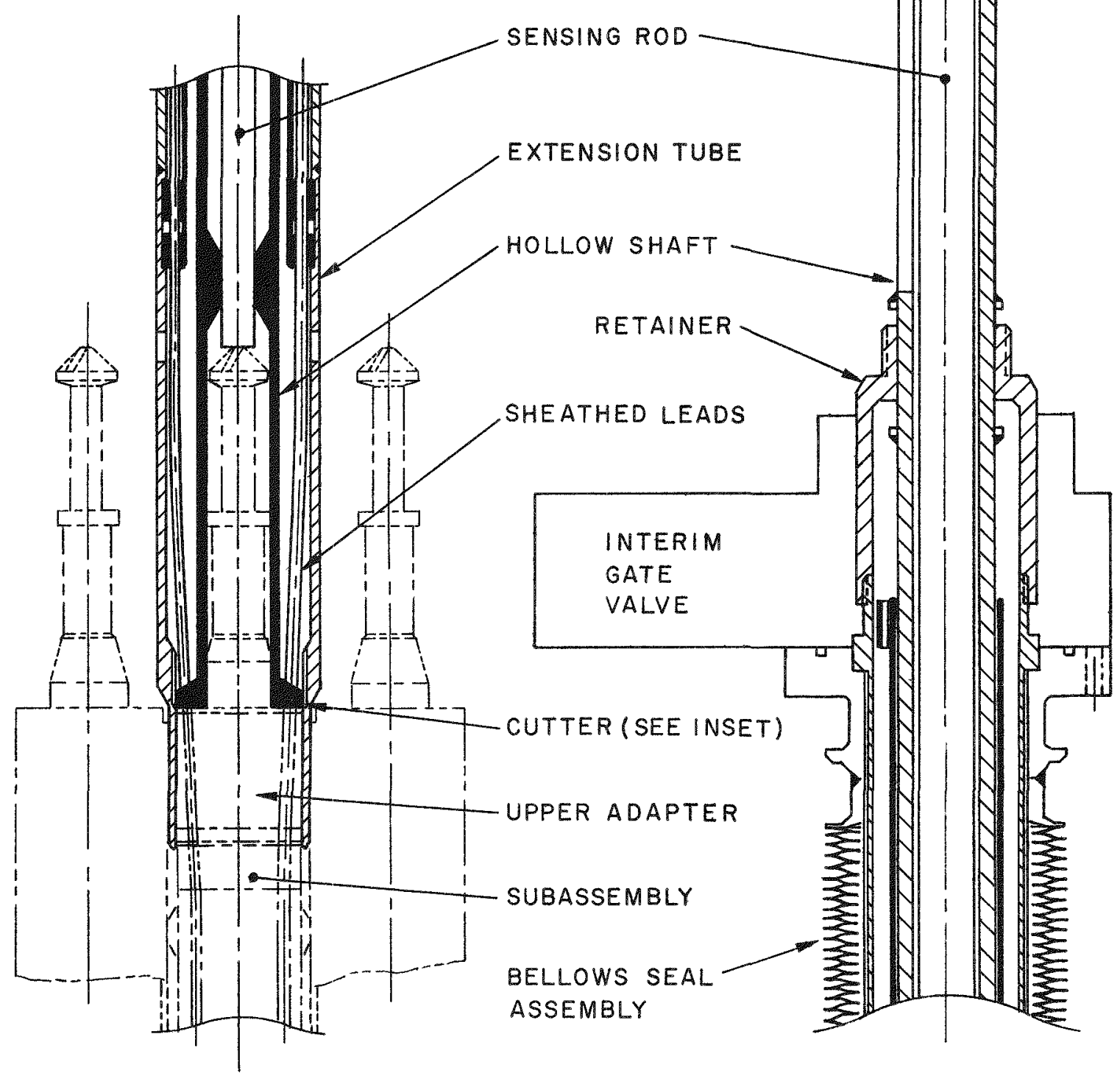

Fig. 19. Cutting Tool Assembly for Severung Leads from Prototype Instrumented Subassembly 


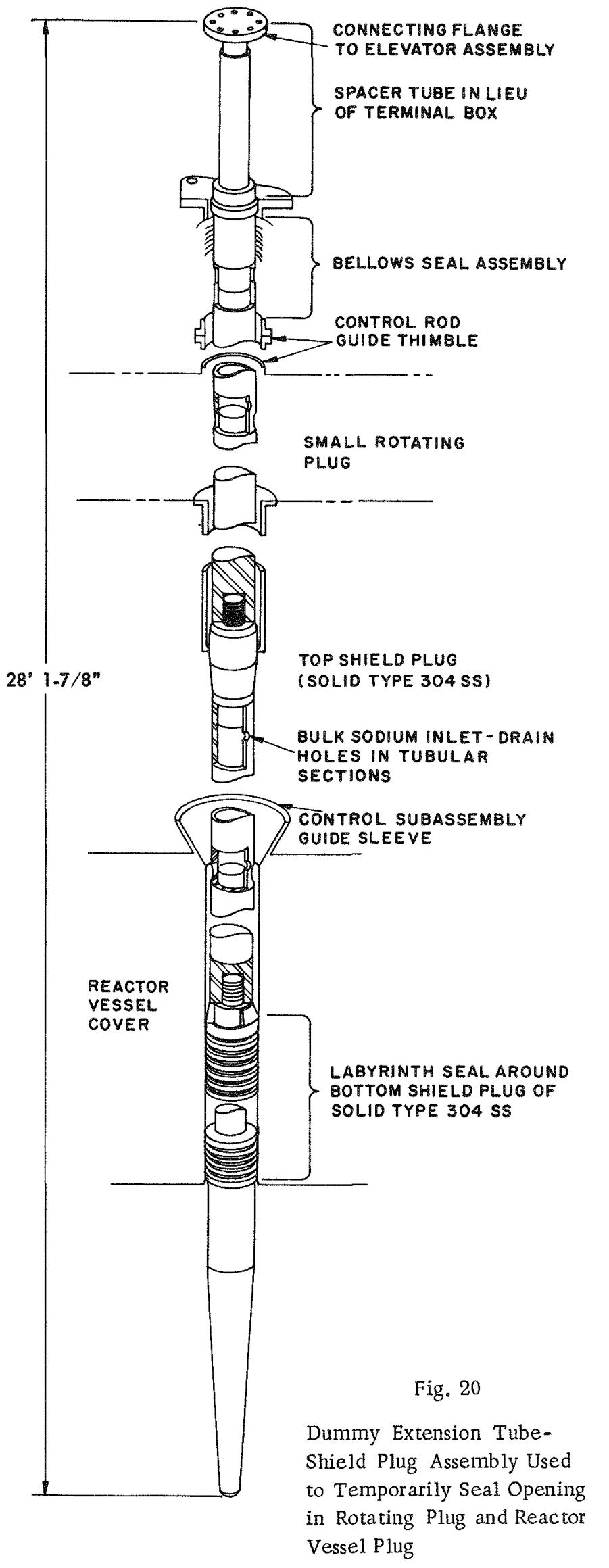

consistent with adapters on replacement Model IHE (Increased Holddown Effect) control-rod subassemblies, which are in final stages of development. ${ }^{6}$ In addition, the lower adapter of the dummy subassembly is orificed with inlet-flow passages so that the effluent coolant temperature approximates that of adjacent subassemblies.

As shown in Fig. 20, the dummy extension tube consists of two solid stainless steel top and bottom plug sections, and two interconnecting tubular sections. These sections are threaded and welded to form a 28-ft $1 \frac{7}{8}$-in.-long assembly, weighing $300 \mathrm{lb}$. Holes are drilled in the top and bottom of each tubular section to permit filling and draining of the bulk sodium coolant during installation and withdrawal of the assembly. The assembly is lowered (with the pulling tube) through, and connected at the top to the flange of, the bellows seal assembly. This flange, in turn, is connected to the flange of the elevator assembly.

When completely installed (1) the upper plug provides shielding in the opening of the small rotating plug; (2) the lower plug provides shielding in the guide sleeve of the reactor-vessel cover; (3) a labyrinth seal around the bottom plug restricts outleakage of primary sodium coolant through the sleeve; and (4) the tapered tip of the bottom plug is suspended $1 / 4 \mathrm{in}$. above the subassembly end fitting as a backup to the restraint provided by the hydraulic holddown. 
Since the dummy extension tube is connected to the elevator assembly, any forces imposed on the tube or plugs during raising or lowering of the vessel cover will activate appropriate safety interlocks in the drive mechanism and fuel-handling circuitry.

d. Processing of Instrumented Subassembly. The capsules will be removed from the subassembly with the Vertical-AssemblerDismantler in the air cell of the Fuel Cycle Facility. First, the lower adapter will be severed with the hexagonal tube cutter. Next, the upper adapter and leads will be severed, and the hexagonal tube removed with the pullout drive. Finally, the capsules will be separated, loaded into ANL-390 SPM containers, and shipped to other sites for postirradiation analyses of their contents.

F. Installation of Additional Instrumented Subassemblies

As mentioned in the Introduction, the objective of this development activity is to install up to four instrumented subassemblies in the 12 controlrod positions. Several reference loading arrangements have been evolved, based upon the following criteria:

(1) A reasonably uniform control-rod spacing.

(2) Installation of an oscillator-rod assembly in position No. 8.

(3) Installation of a rod-drop-test assembly in position No. 1.

(4) Installation of at least one control rod between instrumented subassemblies or between an instrumented subassembly and the oscillatorrod assembly.

(5) Least obstructed access to an instrumented subas sembly.

Figure 21 shows the preferred arrangement. Because the southeast side of the small rotating plug is the least congested area, and on the as sumption that position No. 8 will be used intermittently for reactor kinetic experiments, position No. 6 has been chosen for installation of the prototype subassembly. Additional units may be installed in positions No. 2, 8, and 10. For improved control-rod distribution, position No. 11 could be considered in lieu of No. 10 .

To accommodate multiple installation, control rods of $50 \%$ greater reactivity worth are under development to permit reactor operation with eight control rods. The status of this development effort is reported in Ref. 7. 


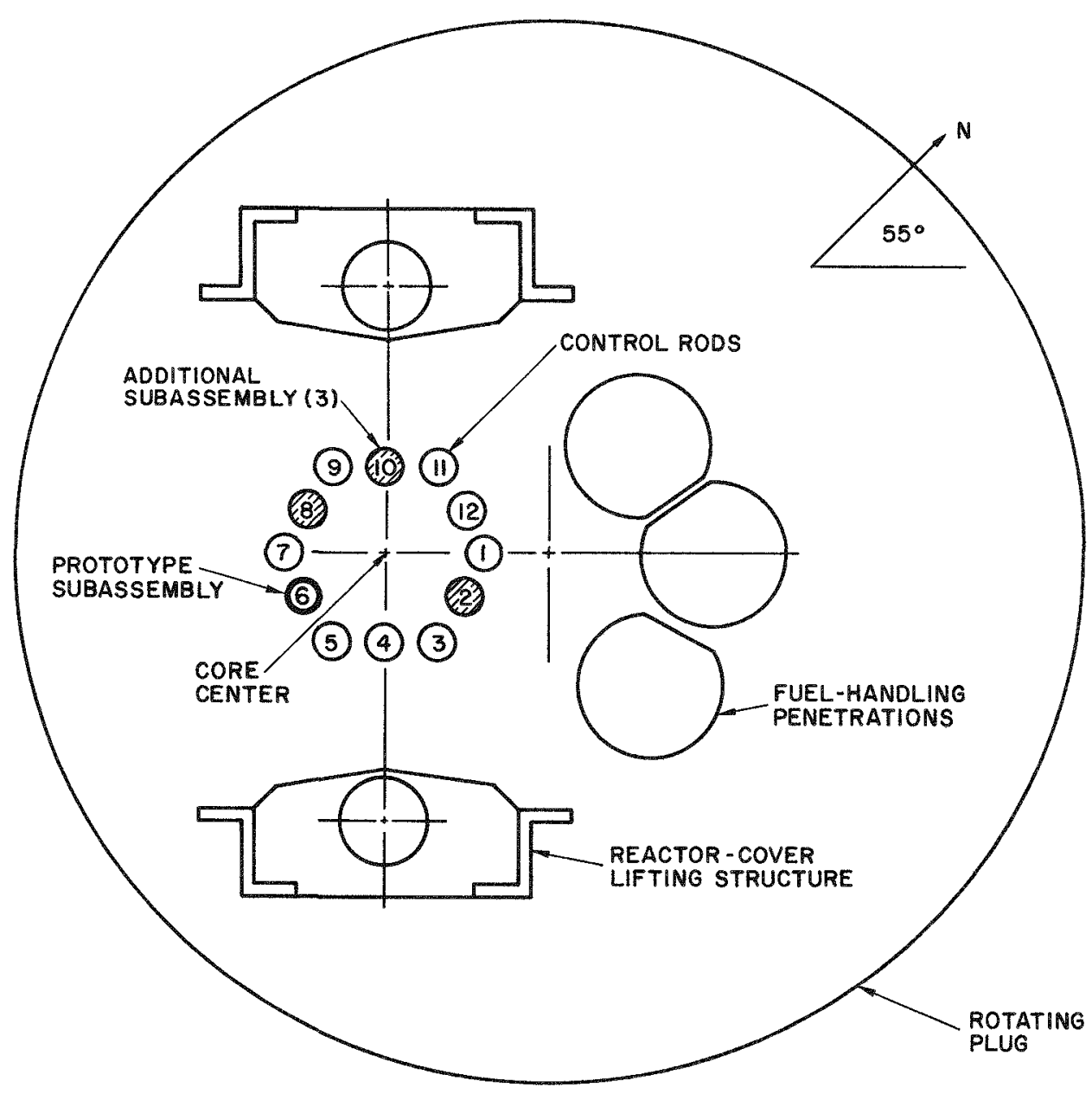

Fig. 21. Preferred Multiple Instrumented Subassembly Installation in EBR-II

\section{ACKNOW LEDGMENTS}

We gratefully acknowledge the assistance rendered by members of the Reactor Engineering Division during the course of this study. In particular, we thank F. J. Simanonis, P. J. Begitschke, V. J. Puchala, and R. W. Mars for their significant design contributions; and D. L. Vetter and his Mechanical Laboratory Group for performing the experimental work.

We also acknowledge L. J. Koch for his helpful suggestions and review of the initial draft, and we are most appreciative to $M$. R. Sims for his aid in preparation of this report. 


\section{REFERENCES}

1. Reactor DeveZopment Progrom Progress Report, ANL-7279 (Nov 1966), p. 5.

2. E. Hutter and G. Giorgis, Design and Performance Characteristics of EBR-II Control Rod Drive Mechanisms, ANL-6921 (Aug 1964).

3. N. J. Carson et al., Fabrication of EBR-II, Core I Fuel Elements, ANL-6276 (Dec 1962).

4. M. C. Glass and G. F. Popper, The Calibration and Stability of a $1200^{\circ} \mathrm{F}$ Permanent Magnet In-Core Sodium Flowmeter, IEEE Trans, on Nuc1. Sci. NS-15, No. 1 (Feb 1.968), p. 37.

5. M. C. Glass and G. F. Popper, The Design and Performance of a $1200^{\circ} \mathrm{F}$ Magnetic Flowmeter for In-Core Application in Sodium-Cooled Reactors, IEEE Trans. on Nucl. Sci. NS-14, No. 1 (Feb 1967), p. 342.

6. Reactor Development Progrom Progress Report, ANL-7317 (March 1967), pp. 13-15.

7. Reactor DeveZopment Program Progress Reports: ANL-7349 (June 1967), pp. 13-14; ANL-7357 (July 1967), pp. 6-7. 